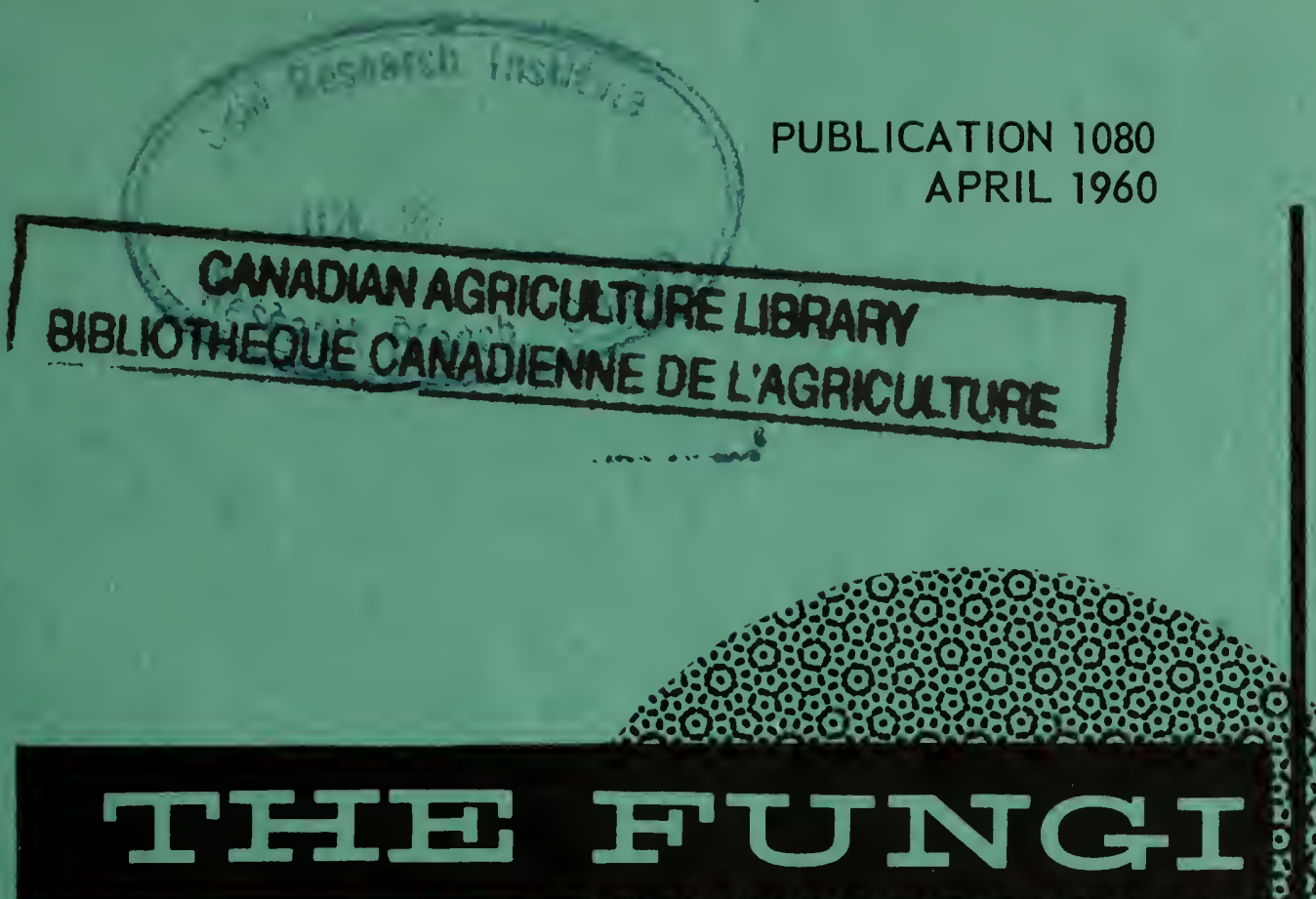

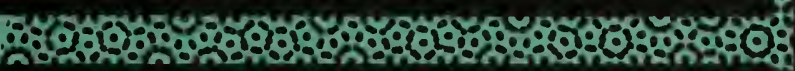

\title{
OI OITIARIO
}

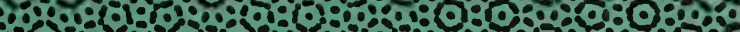

\section{Uredinales}

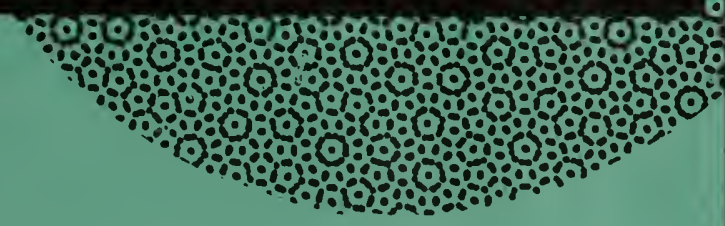

by

John A. Parmelee 


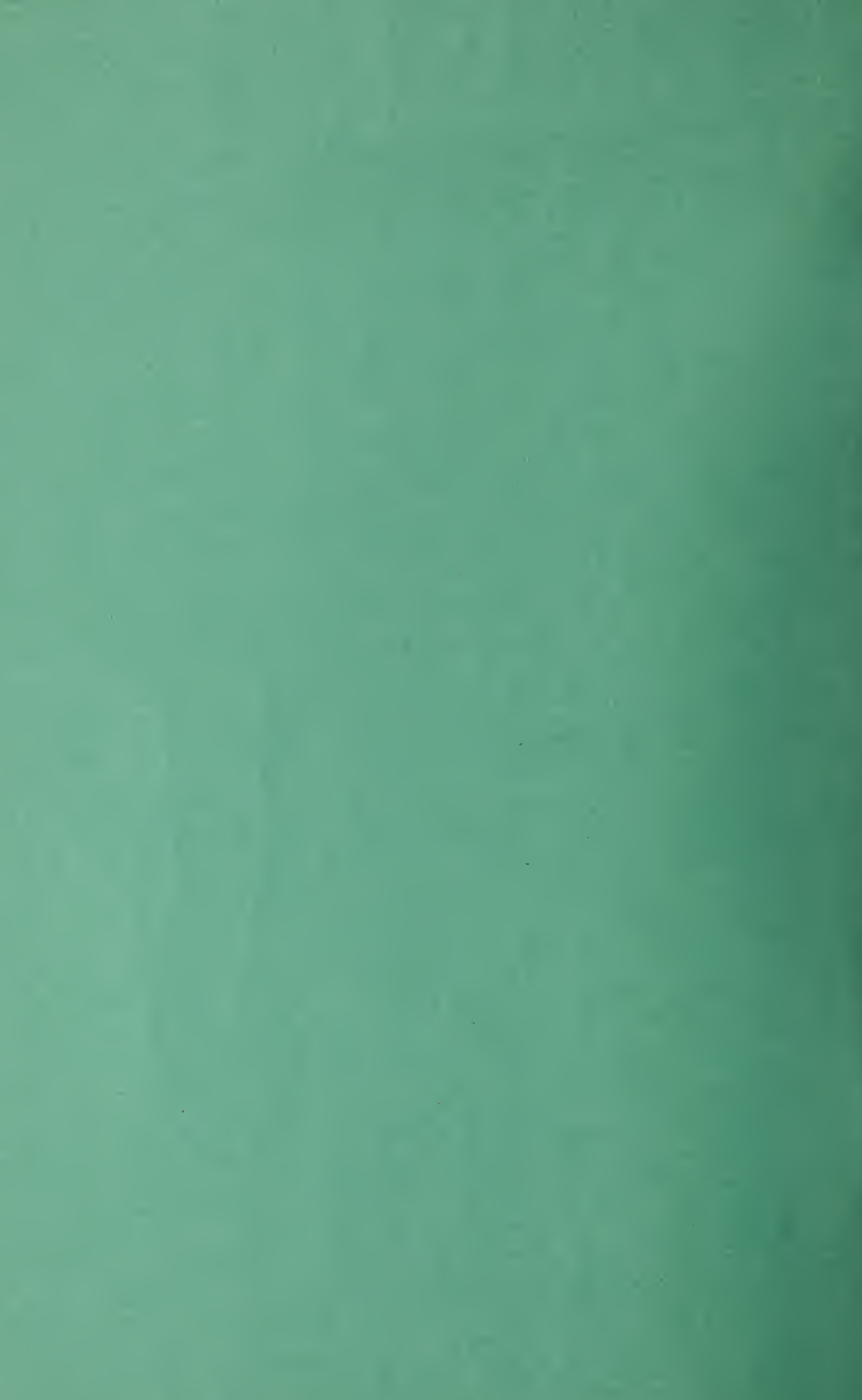




\title{
THE FUNGI OF ONTARIO
}

\author{
1. Uredinales \\ by \\ JOHN A. PARMELEE \\ Plant Research Institute, Ottawa, Ontario
}

RESEARCH BRANCH

CANADA DEPARTMENT OF AGRICULTURE 


\section{CONTENTS}

Page

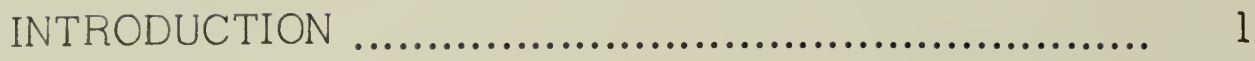

AECIDIIIM ................................................... 3

CHRYSOMYXA …............................................. 4

COLEOSPORIUM ….......................................... 5

CRONARTIUM ................................................. 6

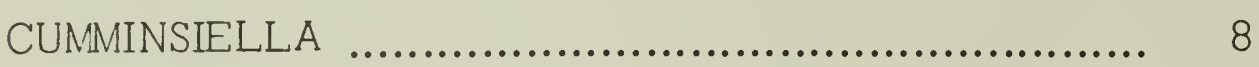

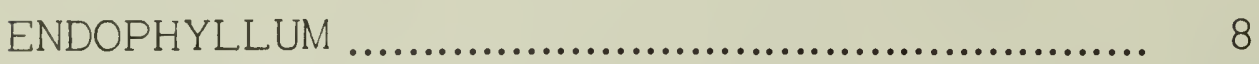

FROMMEA ….............................................. 8

GYMNOCONIA ............................................... 9

GYMNOSPORANGIUM ....................................... 9

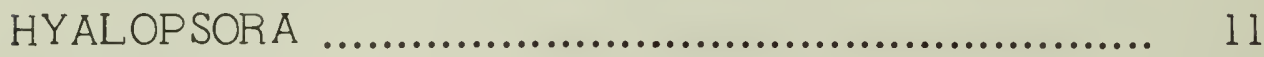

KUEHNEOLA $\quad$............................................... 12

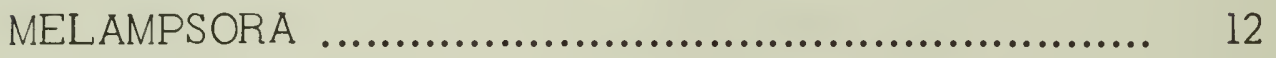

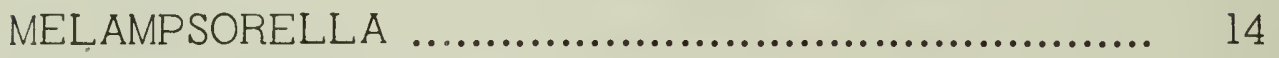

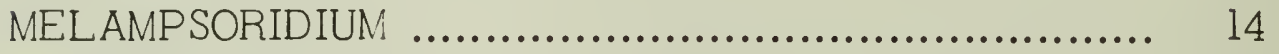

MILESIA ................................................... 14

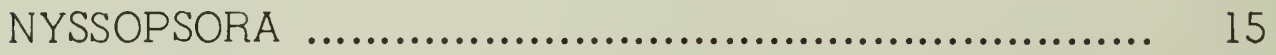

PHRAGMIDIUM ............................................ 15

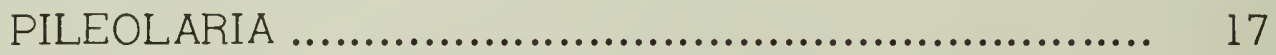

PUCCINIA .................................................. 17

PUCCINIASTRUM N........................................ 33

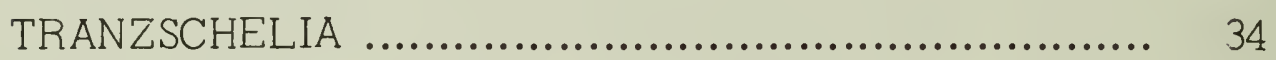

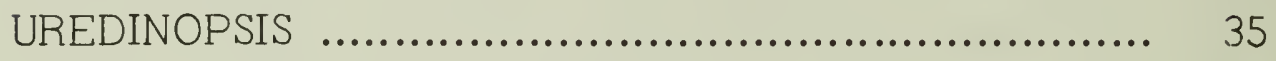

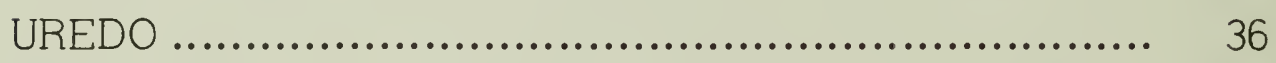

UROMYCES ............................................... 36

REFERENCES ............................................. 40

INDEX TO HOSTS ........................................... 42 


\section{NTRODUCTION}

It is expected that this annotated list of Uredinales will be the first of a series treating the various natural groups of fungi that occur in Ontario. When most of the groups have been so treated by various authors, it may then be possible to present a 'fungus flora' of the area. The present treatment is a revision of a thesis submitted by the author in 1952 in partial fulfillment for the degree of Master of Arts in the University of Toronto.

The species recorded are based primarily on the specimens deposited in the mycological herbarium of the Botany Department, University of Toronto (TRTC), the National Mycological Herbarium of the Department of Agriculture, Ottawa (DAOM), and the private mycological collection of John Dearness (DEARN). Much of the collectina naturally centers around the cities where the herbaria are located and therefore in DAOM there are many specimens that were collected in the 'Gatineau area' in the province of Quebec within a radius of twenty miles of Ottawa. Although they are from outside the boundaries of Ontario these records will be included in this report in order to emphasize that such species are to be sought in adjacent parts of Ontario. For many years (1924-1954) a botanical laboratory was maintained at Lake Timagami in Nipissing District, by the University of Toronto. There, abundant, collecting and culture work was carried out by J.H. Faull, his students, and his successors. Some of this early culture material remains in TRTC.

One of the pioneers in the study of fungi in Ontario was John Dearness. His collections, dating from the late 1880's, are mostly from Middlesex and neighboring counties and are presently housed in DAOM. Some of the Dearness specimens were deposited in the Arthur Herbarium (PUR) maintained at Purdue University, Lafayette Indiana, U.S.A. A record of these and all other Canadian collections of Uredinales in PUR up to the year 1930 was compiled by the late H.S. Jackson and is available at Toronto and Cttawa.

Except for occasional forays emanating from Winnipeg, Man., to Minaki and Kenora, mycological collecting in Ontario north of the forty-ninth parallel has not been extensive. But, as new roads are extended northward and with increasingly convenient air travel, this broad expanse of northland becomes more accessible; and it is hoped that our knowledge of the fungus flora of the area will increase with the improving travel facilities.

The genera and species are arranged in alphabetical sequence. Two hundred and nineteen of the two hundred and thirty three entities treated are known to occur within the provincial boundaries. Species are numbered consecutively to simplify the use of the appended generic host index.

The information on each rust species will include:

1. The name, authority and date of the binomial chosen. Nomenclature follows that adopted by Cummins and Stevenson (1956) who have revised the names of 
North American rust fungi to comply with Article 69 of the International Code of Botanical Nomenclature 1952. Where the revised name does not correspond with the one that appears in Arthur's rust manual (1934) the latter will follow immediately in parenthesis.

2. The number of collections of any species on file in the various herbaria precedes the abbreviation for the particular herbarium. Abbreviations are those used in the 1956 edition of the Index Herbariorum. The main purpose for including the number of specimens on deposit is to indicate what species are poorly represented and thus to direct collecting activities toward them.

If a species is of rare occurrence, the information about existing collections is increased to include, after the abbreviation of the herbarium, the accession number and the county of the collecting site.

3. The geographical range of rust species in the province is given by numerals 1-54 inclusive. These represent the counties and districts of Ontario beginning in the south and following a general pattern northward (See map, pp. 22 and 23)!

4. The various spore stages making up the normal complement for a given species are represented by the accepted symbols 0 I II III for pycnia, aecia, uredinia and telia respectively. Host names immediately follow in alphabetical sequence but without authorities as these are readily obtained from Fernald's (1950) edition of Gray's Manual, Rehder's Manual of Cultivated Trees and Shrubs (1951) or Bailey's. (1949) Manual of Cultivated Plants. Where the host name differs from the published record the latter appears in parentheses following the name now in use.

The host list may be followed by some general remarks concerning the taxonomy and appearance of the fungus, reference to and differences from other species occurring on the same hosts, and occasionally a note about the importance of rust infection in plants of economic value.

5. Records from outside the province but originating from adjacent regions (which suggests probable occurrence within Ontario) are included in square brackets [ ]. Accidental greenhouse occurrences not otherwise known in the field are treated in like manner. Rust records and host records acquired after the publication of Arthur's Manual in 1934, and the Fungi of Manitoba and Saskatchewan by Bisby et al. in 1938 are designated by an asterisk (*).

Explanation of terms:

A number of terms especially applicable to the Uredinales are explained as they find usage in the text. Other terms not specifically treated or of a general application are now considered. A rust is autoecious when the life cycle is completed on one host. If two unrelated hosts are required it is heteroecious and the hosts

1The map (slightly revised) and the numerical system for the counties and districts are taken from "The distribution of breeding birds in Ontario," by J.L. Baillie Jr. and P. Harrington. Transactions of the Royal Canadian Institute 21; 1937. 
are alternate hosts. The complement of stages between one spore form and the development of the same spore form is called the life cycle. A rust that possesses pycnia, aecia, uredinia and telia is macrocyclic (O I II III) or long cycled. Where the complete cycle lacks all stages but telia, or pycnia and telia, it is microcyclic (III or 0 III). Other stages may also be omitted. If a species lacks aecia it is referred to as a brachy-form (O II III); or if uredinia are lacking it is called an opsis-form (O I III). Endo-forms (O I III) lack uredinia and normal telia; the normally appearing aeciospores function as teliospores by producing basidia and basidiospores. Spores germinate through the spore wall at predetermined thin areas called pores or germ pores, which may be covered by hyaline or pale, yellow-brown papillae (sing. papilla). Spore walls may be smooth, sculptured with pointed protuberences (echinulate) or with blunt warts (verrucose). Infection may be local and restricted to the immediate area of infection or it may be systemic in which case it is extensive throughout the host. When the sori occur on the lower, upper or both surfaces of a leaf they are hypophyllous, epiphyllous and amiphigenous respectively.

The writer gratefully acknowledges the aid of many associates in the Plant Research Institute, Ottawa, especially Mr. I.L. Conners who suggested the original thesis and Dr. D.B.O. Savile for his criticism of and his interest in the present paper. Thanks are expressed to Dr. R.F. Cain of the University of Toronto for his suggestions and to Mr. W.D. Sutton of London, Ontario, for permission to examine his personal collections of Uredinales.

\section{AECIDIUM}

When a rust possesses pycnia and cupulate aecia, or just aecia, but has no known telial connection it may be described under the form-genus Aecidium.

1. *A. hydnoideum Berk. \& Curt. 1874 (Puccinia extensicola Plowr. var. hydnoidea (Berk. \& Curt.) Arth.). 2 DAOM, 1 DEARN, 4 TRTC. Range 5, 25, 29, 42, 45, 46. 0 I Dirca palustris. Aecial characters do not agree closely with those of other rusts in the $P$. dioicae ( $P$. extensicola) complex. For example, spores are smaller and there are no pore plugs. Attempts to infect Carex pensylvanica with I spores from Dirca were not successful under greenhouse conditions at Ottawa, and rusted Dirca and Carex have not been found in association in the field. For these reasons the rust on Dirca is treated here under the formgenus.

2. *A. physalidis Burr. 1884. 4 DAOM. Range 40. 0 I Physalis heterophylla. II III unknown. In $1943 P$. heterophylla was found near Ottawa bearing systemic pycnia which, when diploidized manually, later produced aecia. Other leaves, screened against insects and with pycnia not diploidized, produced no aecia. The plants were found to have come with fill from the edge of a sandpit near Ottawa Airport, where several plants bearing the systeriic aecia were found. No alternate host could be found and the colony was destroyed by expansion of the pit before much experimental work could be done. But attempts to germinate the 
fresh spores failed, and this rust is now suspected to be an Endophyllum such as $E$. lacus-regis in which the spores germinate only after overwintering.

\section{CHRYSOMYXA}

Most species are macrocylic and heteroecious, but a few have shortened their life histories. Pycnia and aecia are typically found on needles and cones of Picea. The uredinia and telia occur on various members of the Empetraceae, Pyrolaceae or Ericaceae. In Ontario infection on spruce, especially Picea pungens (blue spruce), which is extremely susceptible to attack, is often cause for concern. Attention is drawn to infected trees because the aecia are so conspicuously bright orange. However, severe infections do not usually occur every year unless the spruce is growing in the vicinity of an alternate host and commonly the worried owner sees little or nothing of the disease in ensuing years. In northern Ontario Empetrum and Ledum are abundant and are usually heavily rusted. Savile (1950) has suggested that this is one of the complex of factors which has kept the invasion of the barren northern regions by spruce to a minimum. The taxonomic treatment here follows that of Savile (1955).

3. ${ }^{*}$ C. arctostaphili Diet. 1894. III Arctostaphylos uva-ursi, scattered on leaves. Lanark Co. DAOM 7190. This is the only known Ontario collection.

4. ${ }^{*}$ C. chiogenis Diet. 1894. 2 DAOM, 3 TRTC. Range 47, 48, 51. 0 I Picea mariana TRTC 418 (inoc. exper.). Scattered on needles. II III Gaultheria hispidula. (Chiogenes h.) localized on leaves but may appear systemic because of very heavy infections. The small inconspicuous nature of the telial host accounts, in a large measure, for the few specimens in Ontario herbaria. A search of phanerogamic collections uncovered the records from Algoma (48) and Thunder Bay (51).

5. [C. empetri Schroet. ex Cumm. 1956 (C. empetri (Pers.) Schroet.). 12 DAOM Great Whale River, Fort George, Rupert House, Que. and Fort Churchill, Man. O I Picea glauca scattered on needles. II III Empetrum nigrum epiphyllous on leaves]. It is expected that this species will be found in Ontario in habitats and latitudes corresponding to sites recorded.

6. C. ledi (Alb. \& Schw.) de Bary 1879. 0 I Picea glauca, P. mariana, P. pungens. 9 DAOM, 6 DEARN, 3 PUR, 9 TRTC. Range 5, 13, 20, 40, 43, 45, 47, 48, 51, 54. var. groenlandici Savile II III Ledum groenlandicum I DEARN, 1 DAOM, 10 TRTC. Range 7, 19, 47, 53, 54. var. cassandrae (Peck \& Clint.) Savile (C. cassandrae (Peck \& Clint.) Tranz.) Chamadaphne calyculata 3 DEARN, 4 DAOM, 3 PUR, 6 TRTC. Range 5, 12, 13, 19, 20, 40, 44, 47, 48. Because it is most difficult to separate varieties in the 0 I stages except if the spruce is exclusively associated with a single alternate host, varietal separations of the aecia are not attempted. Varieties are host specific.

7. C. ledicola Lagerh. 1893. 20 DAOM, 1 PUR, 2 TRTC. Range 40, 47, 48, 51, 53, [Great Whale River and Fort George, Que.]. 0 I *Picea glauca,*P. 
mariana, $P$. pungens scattered on needles. II III $*$ Ledum groenlandicum, $[* L$. palustre var. decumbens], epiphyllous. The location of uredinia on the upper side of the leaves is a ready means of separating this species from $C$. ledi which has hypophyllous uredinia. Heavy infection may cause severe defoliation of spruce in some seasons. It was the reason for Riley's comment: "imparting a conspicuous rusty colour to the forest as seen from the air." (Canadian Plant Disease Survey for 1948).

8. C. pirolata Wint. 1882 (C. pyrolae (DC.) Rostr.).8 DAOM, 2 DEARN, I PUR, 15 TRTC. Range 5, 19, 21, 25, 27, 40,45,47, 51, 53, 54. 0 I *Picea glauca, *P. mariana systemic in cones. II III [*Moneses uniflora] *Pyrola americana, $* P$. asarifolia, *P. elleptica, $P$. minor, $P$. secunda, $P$. virens, $P$. spp. Uredinia hypophyllous and systemic.

9. ${ }^{*}$ C. weirii Jackson 1917. III Picea mariana TRTC 32130 Worthington Bay, Schreiber, Thunder Bay Dist. This is a typical micro-form rust species, one that supports Jackson's (1931) generalization that the majority of microforms probably originated from the haploid mycelium of heterothallic pleomorphic ancestors.

10. [* ${ }^{*}$. woronini Tranz. 1903. 0 I Picea glauca DAOM 23443, 23514 Gt. Whale River, Que. Systemic on current year shoots. III Ledum palustre var. decumbens. Telial collections are not known from this site but there are numerous collections in DAOM from both east and. west coasts of Canada. Infection results in the formation of small witches'-brooms, and the telia are crusted on the underside of current season leaves. A complete description is given by Savile (1950)].

\section{COLEOSPORIUM}

Pycnia and aecia, where known, have been shown to occur on needles of various species of pine and in Ontario, can be found from early May to late June. Uredinia and telia appear on members of the Compositae, Caprifoliaceae and Campanulaceae. Five species are known in Ontario and of these the complete life history is known for all but $C$. viburni. Arthur has describea twenty species from North America. Other than those caused by Chrysomyxa, leaf rusts of conifers, which include Coleosporium, Lredinopsis, Milesia, Hyalopsora, Melampsora and Melampsorella, are not considered to be economically important under forest conditions. They may, however, warrant attention on young nursery stock.

11. C. campanulae Lév. ex Kickx. 1867 (C. campanulae (Pers.) Lév. 1847).9 DAOM, 1 DEARN, 7 TRTC. Range 5,8,11, 19, 25, 26, 28, 32, 35, 40,41, 48. 0 I Pinus resinosa, $P$. rigida not known in Ontario but have been reported from the bordering Great Lakes states. II III ${ }^{*}$ Campanula persicifolia, ${ }^{*}$ C. rapunculoides, ${ }^{*}$ C. rotundifolia, Campanula spp.

12. ${ }^{*}$ C. delicatulum Hedgc. \& Long. 1924. 8 DAOM, I TRTC. Range 1, 40, 43. 0 I Pinus resinosa, $P$. rigida are known hosts but have not been recorded in Ontario. II III Solidago graminifolia. 
13. C. asterum (Diet.) Syd. 1914 (C. solidaginis (Schw.) Thuem. 1878).79DAOM, 14 DEARN, 36 TRTC. Range 4, 5, 6, 8, 13, 17, 19, 20, 21, 23, 25, 28, 30,37, $40,43,44,45,47,48,49,51,53,54$ and [the Gatineau area and Great Whale River, Que.]. 0 I *Pinus banksiana, *P. resinosa. II III Aster ciliolatus ( $A$. lindleyanus) $A$. cordifolius, *A. foliacius, ${ }^{*}$ A. laevis, ${ }^{*} A$. lowrieanus, $A$. macrophyllus, *A. novae-angliae, ${ }^{*} A$. novi-belgii, *A. pilosus, ( $A$. ramosissimus), ${ }^{*} A$. ptarmicoides, *A. puniceus, $A$. sedifolius (A. acris), *A. simplex (A. paniculatus), $* A$. tradescanti, *A. umbellatus, *A. vimineus var. foliosus, Aster spp.; Callistephus chinensis (C. hortensis); *Solidago altissima, ${ }^{*} S$. caesia, S. canadensis, ${ }^{*}$ S. dumetorum, S. flexicaulis (S. latifolia), * S. gigantea, *S. ? glomerata, $S$. hispida, ${ }^{*}$. lepida var. elongata, and var. fallax, ${ }^{*} S$. missouriensis (S. glaberima), *S. mollis, [*S. multiradiata], S. nemoralis, S. patula, *S. racemosa var. gillmani, ${ }^{*} S$. riddellii, $S$. ? rigida, ${ }^{*} S$. rugosa, ${ }^{*} S$. sempervirens, ${ }^{*} S$. shortii, ${ }^{*} S$. speciosa, ${ }^{*} S$. squarrosa, ${ }^{*}$. uliginosa, Solidago spp. A. sedifolius and A. chinensis are cultivated asters and $S$. dumetorum is a western species which was under study at the Dominion Arboretum and Botanic Garden, Ottawa.

14. C. veroniae Berk. \& Curt. 1874. The only collection, DAOM 25437, Essex Co., on Veronia altissima showed heavy uredinial infection. A small windbreak of Pinus sylvestris within 100 yards of the infected Vernonia showed no trace of aecia, as was to be expected in late summer (September). Three species of Vernonia are reported in southern Ontario by Soper (1949) and all Ontario records in DAO are from Essex, Kent and Lambton Counties.

15. C. viburni Arth. 1907. 9 DAOM, 1 DEARN, 8 TRTC. Range 5, 8, 19, 40, 45, 47, 50, 51, and [Gatineau area, Que.]. O I unknown. II III Viburnum cassinoides, $* V$. lentago, *V. raphinesquianum.

\section{CRONARTIUM}

The pycnia and aecia of this group constitute the well-known blister rusts and gall rusts on stems and branches of pines. They complete their life cycle on various herbaceous or woody dicotyledons. The other group of pine rusts, caused by Coleosporium, are evident on needles only, and are therefore readily distinguished. Whereas the needle rusts are relatively unimportant economically, blister rusts have been the cause of much concern, and although elimination of the alternate hosts has effectively reduced the incidence of these rusts, losses are still reported.

16. C. coleosporioides. Arth. 1907. 4 DAOM, 4 TRTC. Range 37, 40, 47, 0 I *Pinus contorta, *P. sylvestris causing galls. II III *Melampyrum lineare. This species is of more importance in Western Canada where $P$. contorta is native. The above collection was taken from a specimen tree at Ottawa. Pomerleau (1942) suggests that $P$. banksiana is a possible aecial host.

17. C. comandrae Peck 1879. 13 DAOM, 2 DEARN, 4 TRTC. Range 5, 8, 11 , 25, 40, 44, 45, 48, 54 [and Great Whale River, Que.]. 0 I Pinus banksiana causing 
fusiform swellings of branches. II III *Comandra pallida, C. richardsiana, $C$. umbellata, Comandra spp. [Geocaulon lividum (Comandra 1.)].

18. C. coniptoniae Arth. 1906. 3 DAOM, 1 DEARN, 7 TRTC. Range 40, 47. 49, 51, 54.0 I Pinus banksiana on branches causing fusiform swelling. II III Comptonia peregrina, Myrica gale. Inoculations of pine(TRT 8372) produced uredinia on both named uredinial hosts. There are evident differences in aeciospore morphology between $C$. comptoniae and $C$. comandrae.

19. C. quercuum (Berk.) Miyabe ex Shirae 1899. 16 DAOM, 3 DEARN 1 PUR, 10 TRTC. Range $1,11,40,44,45,47,49,54$. 0 I *Pinus banksiana, *P. resinosa, $P$. sylvestris causing woody, globose galls. II III ${ }^{*} Q u e r c u s$ rubra, ${ }^{*} Q$. velutina, Quercus spp. on leaves. The record from Essex Co. is a collection on oak, growing in the same general area as a small planting of Scots pine. Hedgecock and Siggers (1949) disagree with Arthur's (1934) treatment of the rust complex on pines and oaks. They would retain specific rank for the entities $C$. cerebrum, $C$. fusiforme, C. conigenum, $C$. strobilum, $C$. quercuum, on the basis of extensive experiments which indicated decided host specificity and which proved that it was not possible to obtain one aecial form using cultures of another. Following the treatment of Hedgecock and Siggers the only entity that would occur in Ontario would be $C$. cerebrum, but Cummins and Stevenson (1956) have indicated that this binomial was never validly published and therefore the name $C$. quercuum has been retained for the purposes of this work.

20. C. ribicola J.C. Fischer 1872. 30 DAOM, 8 DEARN, I PUR, 43 TRTC. Range $1,5,7,8,11,13,17,19,21,27,31,34,40,41,42,43,44,45,46,47$, $48,51,52,54$, and [Gatineau area, Que.] 0 I Pinus strobus on branches and main trunks. II III *Ribes americanum, $R$. cynosbati (Grossularia c.), *R. glandulosum, ${ }^{*} R$. hirtellum, $* R$. lacustre, $R$. missouriense, $R$. nigrum, *R. ? niveum, *R. odoratum, ${ }^{*} R$. oxycanthoides, ${ }^{*} R$. sativum, ${ }^{*} R$. triste, Ribes spp. Records for the Districts of Muskoka, Thunder Bay, Rainy River and Kenora were obtained from a processed report by W.R. Haddow and A.W. Hill (1954) Blister Rust Reconnaissance in Ontario - 1953. They suggest that, because white pine has suffered severe damage as a result of infection by $C$. ribicola in past years, the Ribes population in the proposed planting area should receive critical consideration when reforestation projects using white pine are planned.

21. C. spp. ?"woodgate rust". 4 DAOM, 5 TRTC. Range (?6) 17, 20, 37, 40, 45. 0 I Pinus contorta, $P$. ponderosa, $P$. sylvestris. Unconnected gall rusts have been found which are able to reinfect pines from aeciospores and thus persist and spread without the aid of a perfect state. It is known with certainty what species have this facility but it is possible that many of the rusts with known alternate hosts may also spread in this manner. On the basis of inoculation experiments Boyce (1957) considers the repeating western gall rust Peridermium harknessii to be identical with the woodgate rust of the East, and subsequently uses the name of the telial stage, Cronartium harknessii Meinecke, for both rusts. However, Cummins and Stevenson (1956) have indicated C. harknessii to be a nomen nudum. 


\section{CUMMINSIELLA}

The known species of this autoecious genus all occur on members of the Berberidaceae. It is similar in many ways to Puccinia but differs in having two lateral germ pores in each of the two equal cells of the teliospore.

22. C. mirabilissima (Pk.) Nannfeldt 1947 (C. sanguinea (Pk.) Arth.). 8 DAOM, 1 TRTC. Range 5, 10, 11, 13, 15, 18, 19, 40. 0 I II III Mahonia aquifolium. The rust is not native to Ontario. All early records are from nursery stock intercepted at ports of entry. C. mirabilissima is native to western North America whence it reached Europe about 1923. It is now well established on nursery stock there and much of the stock imported from Europe to Eastern Canada shows intection. The repeated insistence of nurserymen on buying from rusted European sources rather than from healthy local stocks has resulted in the establishment of the disease in Ontario.

\section{ENDOPHYLLUM}

It is commonly accepted that plant rusts have a tendency to shorten their life cycle. This may be accomplished in several ways. One way is by the earlier fusion of the dicaryotic nuclei and the resulting formation of the teliospore. In Endophyllum fusion of the nuclei takes place in the aeciospore, thus the aeciospore germinates with the production of a basidium and basidiospores and in effect functions as a teliospore. The general appearance is that of the aecial stage of Puccinia.

23. E. lacus-regis Savile \& Parmelee 1956. 21 DAOM 5 TRTC. Range 25 and [Gatineau area Que.]. 0 I III on Claytonia caroliniana. The bullate, systemic aecia and the large spores 22-35(-38) x 18-29(-33) $\mu$ of this species allow immediate separation from $P$. marie-wilsoniae G.W. Clint. The latter has cupulate, localized, although often extensive aecial infections, and smaller spores 18-27

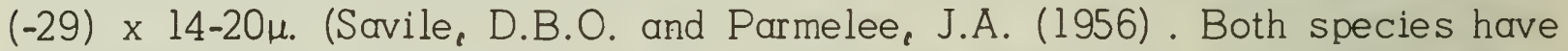
been collected from the same general area but $E$. lacus-regis has a more limited range (cf. P. mariae-wilsonae).

24. E. sempervivi (Alb. \& Schw.) de Bary 1 DEARN, 2 TRTC. Range 5, 19. 0 I III on Sempervivum tectorum, Sempervivum sp., occasionally on leaves of greenhouse and garden plants.

\section{FROMMEA}

One species is known in Ontario and this occurs widely in eastern North America. The characteristics of the pedicellate teliospores are intermediate between those of Phragmidium and Kuehneola. Cells of the multicelled teliospore are firmly united and each cell has a single apical germ pore.

25. F. obtusa (Str.) Arth. 1917. 7 DAOM, 2 DEARN, I TRTC. Range 1, 4, 5, 11, 30, 31, 45. O I II III Potentilla canadensis, $P$. simplex. It is quite possible that herbarium labels bearing the host name Potentilla canadensis should read $P$. 
simplex as these entities were both treated under the former name prior to the 8th edition of Gray's Manual. However it has not been practicable to attempt redisposition of fragmentary host specimens.

\section{GYMNOCONIA}

One species, common in eastern North America, is known to occur on Rubus in Ontario. In general appearance teliospores resemble those of Puccinia but aecia are caemoid, i.e., lack peridia.

26. G. peckiana (Howe) Trotter 1910. 21 DAOM, 2 DEARN, I PUR, 19 TRTC. Range 1, 5, 8, 11, 17, 18, 19, 20, 25, 27, 30, 35,40,43,45,47,48, 54 and [Gatineau area and Ile Perrot, Que.]. 0 I III *Rubus acaulis, R. allegheniensis, $R$. frondosus, $R$. glandulicola, $R$. idaeus var. aculeatissimus and var. strigosus (R. strigosus Michx.), R. occidentalis, *R. pubescens, Rubus sp. In early spring, infected $R u b u s$ is conspicuous by the presence of bright orange pustules crowded on the underside of the leaves. The entire undersurface may be so covered and when whole colonies of Rubus are infected the condition becomes noticeable even from a distance.

27. Kunkelia nitens (Schw.) Arth. 1917 (Gymnoconia nitens Kern \& Thursten 1929) is an endo-form species grossly similar to Gymnoconia peckiana but whose aeciospores germinate with the production of basidiospores. With spore germination as the only certain means of separating Gynoconia and Kunkelia there is reason to suspect that some of the records listed under the former may belong under the latter. Not recorded from Ontario.

\section{GYMNOSPORANGIUM}

Members of this genus generally cause hypertrophy of twigs and needles and produce gelatinizing telia on various species of Juniper. They alternate in the pycnial and aecial stages to some pomaceous segregate of the Rosaceae. Except for one species, which in Canada occurs in British Columbia only, the uredinial stage has been lost from the life cycle.

In Ontario three junipers are commonly infected.

1. Juniperus communis var. depressa is found commonly throughout the province from Essex and Carleton counties in the south to Nipissing and Thunder Bay districts and James Bay. 2. Juniperus horizontalis has a more limited range; it occurs primarily in dry sandy or rocky locations and is recorded from the counties and districts bordering Lake Huron and Lake Superior. In addition Dutilly, Lapage and Duman (1954) record it from Attiwapiskat on the west coast of James Bay. 3. Juniperus virginiana is found in an interrupted range pattern, south of a line from Leeds Co. to Parry Sound District, which in part shows a tendency to follow the southern limits of the Precambrian Zone. For a detailed account of the distribution of this and the previous hosts see Fox and Soper (1953) and Soper, Heimburger and Garay (1957).

Juniperus species other than the above are imported or cultivated. 
28. *G. bermudianum Earle 1892. DAOM 50906, 50907. Collected 21/2 mi. w. of Fernald, Bruce Co. I III *Juniperus horizontalis on globose galls. This is the first Ontario record of this species, which Arthur (1934) reported from the Gulf States, Bermuda and the Bahamas. DAOM 50907 is made up of mature aecia on gails collected in August. An earlier collection (May) showed neither aecia nor telia. In the south telia occur later in the season than the aecia and are produced on the same galls.

29. G. clavariifornie (Pers.) DC. 1805. 18 DAOM, 5 TRTC. Range 16, 25, 27, $33,41,45,47$, and Great Whale River, Que.. 0 I [*Amelanchier bartramiana], $* A$. canadensis, *A. humilis, Amelanchier sp.; ${ }^{*}$ Crataegus oxyacantha on leaves and fruits. III *Juniperus communis var. depressa, [*var. hibernica], [*var. suecica, ], cause fusiform swellings of small to medium-sized branches. The two last-named entities are horticultural varieties, often imported from Holland, and often found rusted when inspected at the various ports of entry.

30. G. clavipes (Cke. \& Peck) Cke. \& Peck 1873. 103 DAOM, 4 DEARN, 5 PUR, 20 TRTC. Range 1, 2, 5, 6, 10, 11, 16, 19, 23, 24, 25, 26, 27, 30, 31, 33, 40, 41, $43,44,45,47,48,51,54$ and [Gatineau area, Que.]. 0 I *Amelanchier alnifolia, A. canadensis, ${ }^{*} A$. florida (A. vulgaris), *A. humilis, *A. huronensis, ${ }^{*} A$. laevis, A. sanguinea, Amelanchier spp.; ${ }^{*}$ Crataegus beata, C. caesia, C. fucosa, ${ }^{*} C$. monogyna, C. oxyacantha, C. punctata, ${ }^{*} C$. succulenta, Crataegus spp.; Cydonia oblonga (C. vulgaris); Pyrus malus, Pyrus melanocarpa, *Pyrus floribunda, Pyrus americana, Pyrus aucuparia, Pyrus decora, causing infection to fruit, twigs even thorns. III Juniperus communis, [among the horticultural variants growing in the Dominion Arboretum and Botanic Garden at Ottawa which have been found rusted are: aurea, aurea-spica, aurea-variegata, suecica.], J. communis var. depressa, $[* J$. conferta, *J. oxycedrus, *J. rigida, *J. sabina, and J. sabino var. tamariscifolia, all exotic species in the Arboretum], J. virginiana on current year and older twigs as brick red, pulvinate pustules. Canadian Plant Disease Survey records indicate that this species causes considerable damage to apple in the Maritimes and eastern Quebec in some years.

31. G. corniculans Kern 1910. 7 DAOM, I PUR, 4 TRTC. Range 25, (?40), 43, 48, 54. 0 I *Amelanchier alnifolia, A. sanguinea, Amelanchier spp. hypophyllous on leaves. III *Juniperus horizontalis telia produced on a globoid galls.

32. G. cornutum Arth. ex Kern 1911 (G. aurantiacum Chev.). 6 DAON, I DEAFN, 6 TRTC. Range 25,44, 47,48, 51, 54, and [Great Whale River, Que.] 0 I Pyrus americana (Sorbus a.), *P. decora causing local infections on leaves. III *Juniperus communis var. depressa appearing as pulvinate pustules on needles or if on twigs then often causing fusiform swellings.

33. G. globosum Farl. 1880. 57 DAOM, 6 DEARN, 11 PUR, 6 TRTC. Range 1, $2,5,6,8,10,11,16,17,19,24,25,26,28,29,30,32,33,34,40$, and [Gatineau area, Que.]. 0 I ${ }^{*}$ Crataegus caesia, C. calopodendron (C. tomentosa), C. chrysocarpa var. phoenicea (C. rotundifolia), C. ? colorata, C. delicatabilis, C. 
floribunda, C. fucosa, C. macrantha, (C. glandulosa), C. oxyacantha, C. pedicillata (C. coccinea), C. punctata, C. sanguinea, Crataegus spp. on leaves. III Juniperus virginiana and the following labeled cultivated varieties in the Arboretum, Ottawa: [Juniperus ? fragans, J. ? pendalosa viridis, J. sabina erecta, J. virginiana vars. canaertii, cinescens, elegantissima, pendula, pendulosa, plumosa alba, pyramidalis, schottii]. Telia wedge-shaped on globoid, perennial galls. Occasionally this species is reported on apple but the common name, hawthorn rust, is aptly applied.

34. G. juniperi-virginianae Schw. 1822. 25 DAOM, 5 DEARN, 6 PUR, 2 TRTC. Range $1,2,3,5,6,8,10,11,16,23,24,30$. 0 I Pyrus coronaria (wild crab), *P. ionensis var. plena (Betchel's crab), Pyrus malus (cult. apple), P. sylvestris. II III Juniperus virginiana on leaves, twigs and fruit. Canadian Plant Disease Survey records for the year 1939 indicate that apple suffered considerable damage in southwestern Ontario. There are no records of this rust from the apple-growing regions adjoining Georgian Bay, and in this connection it is of interest to note that Fox and Soper (1953) have not recorded Juniperus virginiana from the area. It should be remembered that quince rust, $G$. clavipes, occurs in that region and may also infect leaves or fruit of apple.

\section{G. juvenescens Kern 1911 - see G. nidus-avis.}

35. G. nidus-avis Thaxt. 1891 ( $G$. juvenescens Kern). 11 DAOM, 1 PUR, 10 TRTC. Range 1, 5, 6, 25, 46. O I Amelanchier spp. hypophyllous on leaves. III Juniperus horizontalis, J. virginiana. Telia pulvinate on base of needles are, in part, responsible for their juvenile appearance; infection is apparent by the formation of dense witches'-brooms. Telia occasionally appear waferlike and tremelloid on larger branches.

The treatment here follows that of Prince and Steinmetz (1940) and Prince (1946) in considering $G$. nidus-avis and $G$. juvenescens as a single species.

36. [G. sabinae (Dicks.) Wint. 1882. O I Pyrus communis (common pear) not known in North America. III Juniperus chinensis, J. sabina producing irregular, small galls. This is a European rust occasionally found in consignments of the above horticultural junipers from Holland and Germany. It has not been found in the province apart from intercepted material screened at ports of entry and where an occasional infected plant has passed to the consignee. P. \& H. Sydow (1915) list $J$. virginiana as a host; it is therefore important to maintain inspections of imported juniper in order to block entry of this pathogen to the pear-growing areas in the vicinity of Toronto, Hamilton and Niagara where red cedar is abundant].

\section{HYALOPSORA}

Pycnia and aecia, where known, are found on needles of Abies and uredinia and telia occur on fronds of Polypodiaceae. In contrast to the other fern rusts, Milesia and Lredinopsis, which have colorless spores, aeciospores and urediniospores are pigmented. 
37. H. aspidiotus (Magn.) Nagn. 1901. 3 DAOM, 3 PUR, 16 TRTC. Range 18, 19, 20, 42, 45, 47. 0 I Abies balsamea. II III Dryopteris disjuncta.

38. H. cheilanthis (Peck) Arth. 1934. 2 DAOM, 3 TRTC. Range 25, 48, 51. C I unknown. II III Cryptogramma stelleri. Additional collections should be forthcoming from the remaining regions bordering the upper Great Lakes where the majority of the phanerogamic specimens in TRT and DAO have been collected.

39. H. polypodii (Pers.) Magn. 1901. 3 DAOM, 2 DEARN, 1 PUR, 6 TRTC. Range 15,17, 18, 19,26, 39, 47, 51, and [Gatineau area Que.]. 0 I unknown. II III ${ }^{*}$ Cystopteris bulbifera, C. fragilis. The fern hosts are known from Kent Co. to James Bay and the rust will likely be found, therefore, throughout the province except in the southwestern region where the probable 0 I host Abies balsamea does not occur.

\section{KUEHNEOLA}

Teliospores are multicellular and somewhat resemble III spores of Frommea, and like the latter this genus is also autoecious and long-cycled. However, Keuhneola possesses certain telial features that enable immediate identification. Some of these are: the loosely articulated condition of the cells, which readily break up and appear as single "spores"; the prominent apical papilla over the germ pore of each cell; the colorless cell wall and the resulting whitish appearance of the telia in mass.

40. K. uredinis (Link) Arth. 1906. I DAOM 1 PUR, 3 TRTC. Range 5, 8, 11, 19, 40, O I II Ill Rubus flagellaris ( $R$. procumbens, $R$. villosus), Rubus spp. This rust is poorly represented in Ontario herbaria; doubtlessly it will be found on other Rubus species.

\section{MELAMPSORA}

In Ontario two species of Melampsora are autoecious; these occur on Euphorbiaceae and Linaceae. The remainder are heteroecious and in the 0 I stages are found on Larix, Abies or Tsuga and in the II III stages on either Populus or Salix (except some races of M. epitea 0 I on Saxifragaceae.)

Arthur (1934) treats the rusts on Salix under four species, whereas Hylander, Jorstad and Nannfeldt (1953) treat the Salix rusts including the North American $M$. abieti-capraearum, $M$. arctica and $M$. ribesii-purpurea as a single entity, viz., M. epitea Thuem. D.B.O. Savile (in conversation) supports the latter treatment and would include $M$. paradoxa (M. bigelowii). Critical revision of this group has not been attempted in North America, and therefore, although the treatment of Hylander et al. will probably gain acceptance, for the purposes of this paper Arthur's Manual is followed.

Characteristic of the genus is the presence of capitate paraphyses in the uredinia. 
A microcyclic species on cones of Tsuga, Melampsora farlowii may yet be found in Ontario as might the autoecious $M$. hirculi Lindr. known from Chesterfield Inlet N.W.T. on Saxifraga.

41. M. abietis-canadensis Ludwig ex Arth. 1924. 2 DAOM, I DEARN, 2 PUR, 6 TRTC. Range 5, 8, 11, 19, 47. 0 I T suga canadensis no Ont. collections. II III Populus deltoides, $P$. grandidentata, $P$. tremuloides, Populus sp. The typical flat melampsoraceous aecium, which lacks a peridium, is readily distinguished from the corresponding stage of Pucciniastrum vaccinii (q.v.) also parasitic on needles of Tsuga.

42. M. abieti-capraerum Tubeuf 1902. 8 DAOM, I DEARN, 2 PUR, 3 TRTC. Range 5, 8, 11, 19, 40,47, 51. O I Abies balsamea. II III *Salix bebbiana, $S$. cordata, S. humilis, S. lucida, S. nigra, S. ? rubra var. forbyana (cult.), Salix sp.

43. [*M. arctica Rostr. 1888. 2 DAOM. Range, east coast James Bay. 0 I Saxifraga spp. No collections from Ontario or adjacent Quebec. II III Salix arctophila DAOM 20773 Fort George, Que., S. cordata (S. adenophylla) DAOM 19126 Rupert House, Que.]

44. *M. euphorbiae (Shub.) Cast. 1843. 4 DAOM, 2 TRTC. Range 5, 9, 19, 38, 41. 0 I II III Euphorbia cyparissias. The melampsoracious structure of this species is distinct from Uromyces proeminens and $U$. striatus, which also infect leaves of Euphorbia.

45. M. ? larici-tremulae Kleb. 1897. A single collection (TRTC 31024) on Populus fits the description of this European species better than any known North American species. The collection wos taken near Nashville in York Co. where Melampsora abieti-canadensis occurs abundantly. In Europe Larix spp. are known to support the 0 I stages.

46. M. lini (Ehrenb.) Lev. 1847. 6 DAOM, I DEARN, Range 5, 37, 40, 53, 54. 0 I II III *Linum lepagei, L. usitatissimum. L. lepagei is restricted to the shoreline of Hudson and James bays. Although flax has been grown commercially for fiber in some parts of Ontario, rust has never been of serious economic importance. The same cannot be said for the oil flax crop of Western Canada where serious losses from rust were experienced in 1942 to 1948 (Canadian Plant Disease Survey); but, since that period, losses have been reduced where rustresistant varieties are grown.

47. M. medusae Thuem. 1878. 15 DAOM, 2 DEARN, 6 TRTC. Range 5, 6, 12, $19,40,45,47,51$, and [Gatineau area Que.]. O I Larix laricina, L. uralensis. II III Populus deltoides, $P$. balsamifera, $P$. sargentii, $P$. tremuloides, $P$. vernirubens, $P$. sp. (hybrid). $P$. sargentii is a western species and no doubt had 'escaped' from the Dominion Arboretum at Ottawa. P. vernirubens is a European species and, along with the hybrid poplars, it had been found rusted at the Petawawa Forest Experiment Station. 
48. M. paradoxa Diet \& Holw. 1901 (M. bigelowii Thuem.). 7 DAOM, 4 DEARN. 2 PUR, 19 TRTC. Range 5, 8, 11, 13, 17, 19, 25, 32, 30, 31, 37, [Gatineau area Que.]. O I *Larix laricina. II III Salix amygdaloides, ${ }^{*} S$. ? bebbiana, ${ }^{*} S$. cordata, ${ }^{*} S$. discolor, ${ }^{*} S$. lucida, ${ }^{*} S$. nigra, Salix sp.

49. M. ribesii-purpureae Kleb. 1901. I DAOM. O I Ribes spp. II III Salix sp. This is primarily a western rust, the single Ontario record (DAOM 19129) was collected at Ottawa (Westboro).

\section{MELAMPSORELLA}

There is but one species recorded for North America. Infection of Abies and Picea results in the formation of conspicuous witches'-brooms. These distinguish this rust from Chrysomyxa and from the "fern rusts," which also infect fir and spruce. There is evidence that both the fir and spruce races have the ability to repeat on their aecial hosts.

50. M. caryophyllacearum Schroet. 1874 (M. cerastii (Pers.) Schroet.).5 DAOM, 3 DEARN, 2 PUR, 15 TRTC. Range 5, 15, 19, 20, 25, 26, 42, 46, 47, 48, 51, 54 and [Great Whale River, Que.]. 0 I Abies balsamea; *Picea glauca, *Picea mariana systemic and causing witches'-brooms. II III $\left[{ }^{*} C\right.$ erastium alpinum]; ${ }^{*}$ Stellaria graminea, $\left[{ }^{*} S\right.$. longipes], ${ }^{*} S$. media, ${ }^{*} S$. monantha] amphigenous.

\section{MELAMPSORIDIUM}

There are three species reported for North America, one of which is known in Ontario. It has pycnia and aecia on Larix (Arthur 1934) and uredinia and telia on Betula. Alnus and Ostrya are II III hosts for the remaining North American species.

51. M. betulinum (Fr.) Kleb. 1899. O I Larix laricina, not known in Ontario. II III Betula glandulosa TRTC 1568 York Co., TRTC 3307 Ontario Co. These are the only collections on record. Both hosts are common in the province and it is expected that more records will be known from Ontario if the rust is in fact alternating between larch and birch.

\section{MILESIA}

Of the fern rust genera Hyalopsora, Milesia and Uredinopsis, the two latter are similar in having all spore forms colorless, but are distinguished by the urediniospores. In Milesia II spores are obovate to elongate-obovate, walls smooth to echinate. In contrast II spores of Uredinopsis are fusiform and generally possess an apical beak or mucro, walls smooth except for two longitudinal, indistinctly roughened to conspicuously ciliate, ridges. Faull (1932, 1938) has monographed Milesia and Uredinopsis and with regard to the Milesia vs. Milesina controversy in nomenclature argues in favor of the former. Cummins and Stevenson (1956) consider that "the usage of Milesia more nearly conforms to the present code." Three species are known in Ontario, and over thirty throughout the world. 
52. M. fructuosa Faull 1932 (M. intermedia Faull 1932). 1 PUR, 12 TRTC. Range 26, 47. O I Abies balsamea hypophyllous on needles of current year. II III Dryopteris spinulosa var. intermedia hypophyllous. Many of the specimens in TRTC on Abies are the results of inoculation experiments carried out at the former University of Toronto biology station at Timagimi, Nipissing Dist.

53. M. marginalis Faull \& Wats. 1932. 1 DAOM, 3 PUR, 9 TRTC. Range 15, 19, 26, 27, 47, and [Gatineau area, Que.]. 0 I Abies balsamea hypophyllous on needles of current year. II III Dryopteris marginalis hypophyllous. Some of the TRTC specimens on Abies were obtained from inoculation experiments.

54. M. pycnograndis Arth. 1925 ( $M$. polypodophila (Bell) Faull). 2 DAOM, 4 PUR, 16 TRTC. Range 47 and [Gatineau area, Que.] 0 I Abies balsamea hypophyllous not on needles of current year, causing loose witches'-brooms. II III Polypodium virginianum hypophyllous. Some of the TRTC collections on Abies were obtained from inoculation experiments. Morphological features of the fern rust peridermia are all very similar, but it is possible that critical study of this stage will provide usable distinguishing features. Until this is accomplished reliable identification of the peridermia must depend on association of the fern host or on inoculations.

\section{NYSSOPSORA}

With telia as the only known stage, this group is readily recognized because of the arrangement of the cells. These are arranged in such a manner that each one touches the other two in this way giving a blunt triangular appearance to the spore. The two North American species are separated on appearance of spines.

55. N. clavellosa (Berk.) Arth. 1912. 4 DAOM, 2 DEARN, 2 PUR, 8 TRTC. Range 5, 10, 47, 48, 51. III Aralia nudicaulis, Aralia sp. Localized telia appear on the upper leaf surface only. Spines arising from the spore wall are branched at the ends.

\section{PHRAGMIDIUM}

These rusts are autoecious, generally long-cycled, and cause local infections in leaves of plants in the Rosaceae. P. speciosum has no uredinia and causes noticeable stem cankers. Teliospores are one- to many-celled (all species presently recorded from Ontario are multicellular) and pedicels are often, but not always, hygroscipic. Keys to the species in Arthur (1934) are based primarily on host connection and teliospore characteristics, while Cummins (1931) provides a key based on host connection and aecial characteristics. In Ontario there have been periodically severe and isolated outbreaks of Phragmidium rusts. A severe outbreak was reported from Lincoln Co. in 1931; and in 1938 heavy infection was reported on wild and cultivated roses in the regions of the Lake of the Woods (Canadian Plant Disease Survey).

56. P. americanum (Peck) Diet. 1905. 9 DAOM, 6 DEARN, 6 PUR، 6 TRTC. Range $1,3,4,5,17,25,27,30,40,47,48,49$. 0 I II III *Rosa acicularis, $R$. 
blanda, R. carolina, ${ }^{*} R$. setigera var. tomentosa, Rosa sp.

57. P. andersoni Shear 1902. I DAOM, 2 DEARN, 3 PUR, I TRTC. Range 3, 25 and [Norway Bay, Pontiac Co., Que.]. I II III *Potentilla fruticosa. Pycnia have not been described. $P$. fruticosa ranges throughout much of the province and is found in rocky or gravelly habitats. Collections from additional parts of the province should be forthcoming.

58. [*P. arcticum Lagerh. ex Liro 1909. O I II III Rubus acaulis DAOM 23630, 23669 Gt. Whale River, Que. R. acaulis is known from the Ontario side of James Bay and it is probable that the rust occurs there also. This is a European entity which was not treated by Arthur (1934). For description, see Saccardo (1912) or Sydow (1915)].

59. P. fusiforme Schroet. 1870 (P. rosae-acicularis Liro). 2 PUR, 3 TRTC. Range 47, 49, 50, 51. O I II III Rosa acicularis var. bourgeauiana, $R$. arkansana var. suffulta (R. heliophila, R. suffulta), Rosa spp.

60. *P. ivesiae Syd. 1903. 29 DAOM, 2 DEARN, 19 TRTC. Range 1, 2, 5, 6, 8, $11,12,15,17,18,19,23,25,27,28,30,32,40,41,42,43,44,45,46,48,51$ and [Ottawa valley, Que.]. I II III Potentilla norvegica ( $P$. monspeliensis), $* P$. recta. This western rust began to appear in Ontario and Pennsylvania about twenty-five years ago. The earliest Ontario collection is TRTC 5670, Lincoln Co., 1933. All collections but one (DAOM) are on $P$. recta. Teliospore wall is verrucose at the apex, smooth below (cf. $P$. potentillae).

61. P. mucronatum (Pers.) Schlecht. 1824 (P. disciflorum (Tode) James). 10 DAONi, 2 DEARN, 1 PUR, 3 TRTC. Range 5, 7, 11, 17, 24, 30, 40, 45, 47, and [Hull, Que.].0 I II III *Rosa blanda, Rosa spp.

62. *P. potentillae (Pers.) Karst. 1879. 0 I II III *Potentilla pallida, *P. recta. There are only two collections from Ontario, DAOM 6443 Carleton Co., and DAOM 6475 Waterloo Co. Entire teliospore wall smooth, pedicel noticeably longer than in $P$. ivesiae.

63. P. rosae-pimpinellifoliae Diet. 1905 ( $P$. subcorticinum Wint.). 3 DAOM Range Apple Hill in Glengarry Co. and [Hull and Montreal, Que.]. 0 I II III Rosa blanda, Rosa spp.

64. P. rubi-idaei (DC.) Karst. 1879. 8 DAOM, 2 DEARN, 2 PUR, 1 TRTC. Range $5,8,17,29,46,47$, and [Fort George and Great Whale River Que.]. 0 I II III Rubus idaeus and two varieties aculeatissimum and strigosus.

65. P. rubi-odorati Diet. 1905. 2 DAOM, 2 PUR, 3 TRTC. Range 10, 19, 33, 40, 42, and [Gatineau area, Que.]. I II III Rubus odoratus.

66. P. speciosum (Fr.) Cooke 1875. 10 DAOM 5 TRTC. Range 18, 19, 30, 38, 40, 45, 54 and [near Montreal, Que.]. 0 I III Rosa acicularis. R. blanda, Rosa spp. This is the only Phragmidium that does not possess uredinia. It is the cause of unsightly and sometimes severe stem infections of roses. 


\section{PILEOLARIA}

Teliospores resemble those of Uromyces except that they are vertically flattened. Urediniospores bear characteristic longitudinal wall markings. Infection by this genus is limited to species of Rhus.

67. P. brevipes Berk. \& Rav. 1874 (P. toxicodendri (Berk. \& Rav.) Arth.). 8 $\mathrm{DAOM}_{\varepsilon} 5$ DEARN, 4 PUR, 6 TRTC. Range $3,4,5,11,15,19,25,40,41,47,51$ and [Bristol, Fontiac Co. and Senneville, Jacques Cartier Co., Que.]. The range of this species extends across Canada. O I II III Rhus aromatica, $R$. radicans (poison ivy). All Ontario collections are of the II III stages.

\section{PUCCINIA}

All types of life cycles are represented among the numerous species (over one hundred in Ontario) of this the largest single genus in the Uredinales. A number of species are rather complex in occurring on many hosts, exhibiting slight or no morphological differences but some biological specialization. Throughout the years these species have been lumped together, split into varieties or treated as distinct species; thus the number of species in any given geographical area will be modified slightly by the inter pretation given to them. Most species are localized in infection, but a few are systemic.

Pycnia are of little use in the identification of species, and aecia are just occasionally distinctive. Aecia are generally cupulate with lacerate and recurving peridia or rarely bullate, opening by a pore. Uredinia are usually pulverulent, foliicolous, caulicolous or both, and light yellow to brown in color. Telia are darker, pulverulent or pulvinate and are also found on leaves and stems. Teliospores are two-celled and are borne on separate, simple pedicels. Spore walls are almost always colored, often but not always thickened at the apex and may be smooth or variously sculptured. Besides dimensions and shape of urediniospores and teliospores, wall thickness, color and marking, pore number and arrangement are among the morphological features used in the identification of species.

68. *P. acetosae Koern. 1876. O I unknown. II III Rumex acetosella DAOM 20658, 62510, Carleton Co.

69. P. andropogonis Schw. 1832. 3 DAOM, 3 DEARN, 5 PUR, 5 TRTC. Range $2,5,25,27,40,54$ and [Bristol, Que.]. 0 I Comandra richardsiana, C. umbellata, Penstemon hirsutus. II III Andropogon gerardii (A. provincialis, A. furcatus), ${ }^{*} A$. scoparius.

70. P. anemones-virginianae Schw. 1822. 9 DAOM, 2 DEARN, 5 TRTC. Range $4,5,7,11,13,15,17,19,28,34,45$ and [Hull, Que.]. III $*$ [Anemone cylindrica], A. riparia, A. virginiana. The majority of collections in DAOM are reported on Anemone virginiana; many of the hosts may actually be A. riparia, but without fruiting heads in the collections checking cannot be done with certainty. 
71. P. angelicae (Schum.) Fckl. 1870. 0 I II III *Taenidia integerrima DEARN 3532 Lambton Co. Angelica atropurpurea and Zizea aurea are probable hosts in Ontario; the latter is known in rusted condition from Manitoba and Quebec.

72. $P$. angustata Peck 1873. 12 DAOM, 4 DEARN, 33 TRTC. Range 3, 4, 5, 7, $8,13,19,25,26,40,45,47,54$ and [Bristol, Que.]. 0 I Lycopus americanus, L. asper, L. rubellus, L. unifolius, L. virginicus, Lycopus sp.; *Mentha arvensis; *Senecio aureus. II III *Eriophorum tenellum, E. virginicum forma album; *Scirpus atrocinctus, S. atrovirens, S. cyperinus, S. pedicillatus, S. rubrocinctus, Scirpus $\mathrm{sp}$. Aeciospores are finely verrucose with scattered groups of coarser markings whereas those of $P$. menthae are larger and coarsely verrucose. A single collection is from Minaki, Kenora Dist. (Bisby et al. 1938).

73. F. antirrhini Diet. and Holw. 1897. 3 DAOM, 3 DEARN, 5 TRTC. Range 1, $2,5,7,11,17,33,40$. 0 I unknown. II III Antirrhinum majus. Infection of snapdragons occurs in the open or in the greenhouse. An illustration of how a plant disease can be spread unintentionally by human agency is illustrated by a specimen in TRTC (ex Herb. J.H. Faull 4461), collected at Lake Timagami. A notation on the label reads "in flower pots sent up from Toronto." A small inoculum potential was transported over two hundred miles to an area not known to have this disease.

74. P. arabicola Ell. \& Ev. 1891. O I III DAOM (Canadian Fungi 157) collected at Ottawa, Ont. This is probably part of the type collection which was originally described as on Arabis confinis. The host was later redetermined (Orton and Arthur N.A.F. 7:459. 1921) and was considered to be Cardamine douglasii; but no James Fletcher collection of any Cardamine species from the Ottawa district matches the rusted leaf, which agrees much better with Arabis divaricarpa, a species he did collect at Ottawa.

75. [*P. araliae Ell. \& Ev. 1891. III DEARN 9044 on Panax trifolius collected at Senneville, Que. This is the third known collection site in North America, Arthur (1934) reports the other collections from Massachussets and Pennsylvania].

76. $P$. arenariae (Schum.) Wint. 1880. III DEARN 2171 on *Spergula arvensis Dufferin Co. It will probably be found on other Caryophyllaceae native to northern Ontario for Arenaria peploides, Cerastium alpinum and Stellaria spp. have been found infected in areas of Manitoba and Quebec bordering Hudson Bay.

77. P. asparagi DC. 1805. 2 DAOM, 4 DEARN, 5 TRTC. Range 2, 4, 5, 7, 11 , 17, 21, 30, 40. O I II III Asparagus officinalis. After the introduction of rustresistant host varieties losses from this pathogen dropped sharply. All Ontario specimens are of uredinia and telia, aecia not having been collected.

78. P. asteris Duby 1830. 11 DAOM, 6 DEARN, 7 PUR, 17 TRTC. Range 4, 5, 10, 19, 25, 30, 40, 43, 47, 48, 51, 54. III Aster cordifolius, A. laevis, A. macrophyllus, *A. novae-angliae, A. puniceus, Aster spp. 
79. P. atropuncta Peck \& Clint. 1879. I DEARN, I PUR, I TRTC. Range 25, 46. 0 I Prenanthes trifoliolata (Nabalus $t$.) no Ontario collections. II III Zigadenus glaucus (Z. chloranthus).

80. P. bardanae (Wallr.) Cda. 1840. 4 DAOM, 2 DEARN, I PUR, 12 TRTC. Range $4,5,8,11,17,18,19,40,47.0$ II III Arctium minus. Aecia lacking. In this respect and in general morphology it compares closely with $P$. cirsii Lasch on species of Cirsium. P. cirsii Lasch and $P$. bardanae are treated as synonyms of P. calcitrapae DC. (q.v.) by Hylander, Jorstad and Nannfeldt (1953). See also P. cnici.

81. [*P. bistortae (Str.) DC. 1815. O I Umbelliferae. II III Polygonum spp. There are no Ontario records but collections from Quebec and Manitoba suggest the occurrence of this species in Hudson and James Bay areas on Polygonum viviparum. Hylander, Jorstad and Nannfeldt (1953) note that on Polygonum the rust is independent of host alternation.]

82. [*P. blyttiana Lagerh. 1892. III Ranunculus pedatifidus var. leiocarpus. Not known in Ontario but it occurs on this host at Chesterfield Inlet, N.W.T.e and the host is known from Akimiski Island and Cape Henrietta Maria.(Dutilly et al 1954)].

83. P. bolleyana Sacc. 1891. 5 DEARN, 3 PUR, 2 TRTC. Range 5, 8, 19, 43, 51. O I *Sambucus canadensis, *S. nigra, Sambucus sp. II III Carex lupuliformis, ${ }^{*}$ C. lupulina.

84. *P. calcitrapae DC. 1805 ( $P$. cirsii Lasch 1859). 2 DAOM, 2 DEARN. Range 5, 25. 0 II III Cirsium vulgare. If the treatment of Hylander, Jorstad, and Nannfeldt (1953) is followed the records of $P$. bardanae should be included here (cf. P. cnici).

85. P. calthae Link 1825. I DAOM, 3 DEARN, 2 PUR, 2 TRTC. Range 4, 5, 7, ?16, 27, 54. O I II III Caltha palustris. Distinctive spore features are: II pores superequatorial, III walls smooth (cf. $P$. calthicola).

86. P. calthicola Schroet. 1879. O I II III Caltha palustris. There are 5 specimens in 'TRTC from York and Simcoe Co. Distinctive spore features are: II pores \pm equatorial, III walls minutely verrucose. Separation of this species from the preceeding one may not be possible without II and III spores.

87. P. canaliculata (Schw.) Lagerh. 1894. O I Ambrosia and Xanthium spp. no Ontario collections. II III Cyperus strigosus TRTC 8172 Kent Co., DEARN 320 Middlesex Co., [C. esculentus, DAOM 23379, 44840 Gatineau Co., Que., along Ottawa River].

88. P. caricina DC. 1815 (P. caricis (Schum.) Schroet. 1887). 17 DAOM, 15 DEARN, 15 PUR, 49 TRTC. Range 1, 3, 5, 7, 11, 15, 19, 25, 40, 42, 43, 47, 48, 51, 53, and [Gatineau area, and Gt. Whale River, Que.]. Throughout the province, probably to Hudson Bay. This is a complex rust with pycnia and aecia 
on Saxifragaceae and Urticaceae, and uredinia and telia on Carex (Cyperaceae). Arthur divides the complex into 5 varieties based on pore arrangement and size of urediniospores. Hylander, Jorstad and Nannfeldt (1953) have lumped these varieties under de Candolle's binomial and have included $P$. limosae (q.v.), in one of 3 additional varieties. There may be merit in accepting the latter treatment in principle; however additional study might indicate the necessity for the retention of some of Arthur's varieties. Pore plugs are present in the aecia of this complex. $O$ I Ribes americanum $\left(R\right.$. floridum), $R$. cynosbati, ${ }^{*} R$. glandulosum, ${ }^{*} R$. hirtellum var. calcicola, ${ }^{*} R$. hudsonianum, $R$. lacustre, ${ }^{*} R$. nigrum, ${ }^{*} R$. oxyacanthoides, Ribes spp.; Urtica dioica, U. gracilis, *U. lyalli, Urtica sp. II III [Carex aquatilis], ${ }^{*}$. arctata, [C. bigelowii], C. blanda, ${ }^{*} C$. brunnescens, C. canescens, C. colorata, ${ }^{*} C$. crawfordii, C. crinita, C. debilis (C. flexuosa), ${ }^{*}$ C. demissa, C. eburnea, C. flava, C. gracillima, C. hirtifolia (C. pubescens), C. intumescens, ${ }^{*} C$. lacustris, ${ }^{*} C$. lenticularis, ${ }^{*} C$. pedunculata $*[C$. ? plantaginea], ${ }^{*}$. . pseudo-cyperus, ${ }^{*}$ C. rostrata var. utriculata, ${ }^{*}$ C. scabrata, C. stricta var. strictior $\left(C\right.$. strictior), ${ }^{*} C$. tetanica, ${ }^{*} C$. trisperma, ${ }^{*} C$. vesicaria, $C$. vulpinoidea, Carex spp.

89. P. caricis-shepherdiae J.J. Davis 1924. 5 DAOM, 2 DEARN, 5 TRTC. Range 3, 25, 30, 40, and [Great Whale River, Que.]. O I Shepherdia canadensis aecia are hypophyllous, scattered or in loose groups. (cf. P. coronata). II III Carex eburnea, *[C. bieglowii]. Excellent field proof of the alternation between Shepherdia and carex was found at Great Whale River where Carex bigelowii (DAOM 23609) grew up through Shepherdia canadensis (DAOM 23592). In Western Canada Elaeagnus is often the 0 I host.

90. [*P. carthami Cda. 1840. O II III Carthamus tinctorius. A number of specjmens in DAOM resulted from inoculations carried out in the greenhouses of the Laboratory of Botany and Plant Pathology, Ottawa. Here, in 1943, the pycnial stage was obtained and experiments showed aecia to be absent and that it was possible to infect the closely related composite Centaurea cyanus very sparingly (Canadian Plant Disease Survey for 1949).]

91. [P. chrysanthami Roze 1900. 3 DAOM, I DEARN. Range 3, 5, 11, and [Montreal, Que.]. O I Unknown. II III Chrysanthemum sp. (Cult.). All specimens are from greenhouses and they include uredinia only.]

92. *P. cicutae Lasch. 1845. 0 I II III Cicuta maculata DAOM 26748, 26753 Carleton Co. A few plants in a large but scattered population growing along a railway ditch were heavily infected and the effect of the rust on the host was visible at some distance.

93. P. circaeae Pers. 1801. 12 DAOM, 4 DEARN, 3 PUR, 18 TRTC. Range $1,2,4,5,7,8,10,11,14,17,19,25,27,40,42,46,47,48,51$ and [Gatineau area, Que.]. III Circaea alpina, C. quadrisculata (C. lutetiana auct., C. latifolia).

94. P. clintonii Peck 1876. DAOM 61811 III Pedicularis canadensis DEARN 1922 Middlesex Co., DAOM 44021 Sturgeon Lake, Petawawa, Renfrew Co. Ont. 
and [DAOM 15465 Gatineau area, Que.].

95. P. cnici Mart. 1817. 3 DAOM, I DEARN, 5 TRTC. Range 5, 19, 25, 40, 47. 0 I II III Cirsium vulagre (C. lanceolatum). Telial collections must be examined carefully to distinguish this species from $P$. calcitrapae DC. ( $P$. cirsii Lasch), which differs mainly in the placement of the germ pore of the lower cell. In $P$. cnici it is located at the septum whereas in $P$. calcitrapae it is much depressed.

96. *P. comandra Peck 1884. III Geocaulon lividum (Comandra lividum) DAOM 28034 Heron Bay, Thunder Bay Dist. This is a new species record for Ontario and a new host for the rust.

97. P. conglomerata (Strauss) Roehling 1813. 3 DAOM, I PUR, I TRTC. Range 40, 51, 54 and [Great Whale River, Que.]. III Petasites palmatus, * [P. sagittatus], $* P$. vitifolius ( $P$. trigonophyllus).

98. *P. convolvuli Cast. 1842. 5 DAOM, I DEARN, I PUR, I TRTC. Range 1, 5, 19, 40 and [ Ile Perrot, Que.]. 0 I II III Convolvulus sepium. There are no Ontario specimens of the 0 I stages.

99. F. coronata Cda. 1837. 53 DAOM, 6 DEARN, 4 PUR, 17 TRTC. Range 3 : $5,8,11,17,19,21,22,24,25,27,28,31,34,36,38,39,40,41,47,51,53$ and [Gatineau area, Que.]. 0 I Rhamnus alnifolia, R. cathartica, Rhamnus sp., and the following named exotic specimens in the Dominion Arboretum and Botanic Garden, Ottawa: $R$. chlorophora $R$. infectoria, $R$. japonica, $R$. pallasii, $R$. saxatilis, $R$. spathulaefolia, $R$. utilis, $R$. wildenowiana. II III *Agropyron repens, Agropyron sp.; *[Agrcsiis stolonifera]; [Avena longiglumis], A. sativa, [A. strigosa], Avena sp.; *Calamagrostis canadensis; *Elymus canadensis; *Festuca elatior; [Lolium perenne]. In Ontario leaf rust of oats is sometimes of considerable economic importance. It was especially severe during the years 1921-24; the ensuing years showed less severe outbreaks but rust was still of local importance depending on the proximity of the buckthorn host, the maturity of the oat crop, and the correlated climatic conditions. An account in the Canadian Plant Disease Survey for the year 1931 describes the oat - buckthorn association which is usually required to produce severe rust infection.

100. P. cryptotaeniae Peck 1873. 0 III Cryptotaenia canadensis DEARN 250 Middlesex Co., TRTC 9538 York Co.

101. P. cyani Pass. 1874. 4 DAOM, 1 DEARN, 4 TRTC. Range 5, 11, 19, 40. 0 II III Centaurea cyanus (bachelor's-button, cornflower) is well known and widely cultivated in flower gardens whence originated these records.

102. P. dayi Clint. ex Pk. 1876. I DAOM, 5 DEARN, 5 PUR, 4 TRTC. Range $5,6,8,40$. III Lysimachia ciliata (Steironema ciliatum). Teliospores are normally 2-celled but occasionally 3- or 4-celled.

103. P. dioicae P. Magn. 1877 (P. extensicola Plow.).20 DAOM, 12 DEARN, 43 PUR, 43 TRTC. Range 1, 2, 3, 4, 5, 6, 8, 11, 13, 15, 16, 18, 19, 25, 26, 40, 43, 


\section{INDEX TO COUNTIES} AND DISTRICTS

\begin{tabular}{|c|c|}
\hline \multirow{2}{*}{ Algoma } & \\
\hline & \\
\hline rur & \\
\hline n.. & \\
\hline ........... & \\
\hline ufferin & \\
\hline 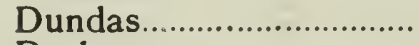 & \\
\hline m & \\
\hline …................... & \\
\hline …........... & \\
\hline nac & \\
\hline & \\
\hline 列 & \\
\hline ................ & \\
\hline .......... & \\
\hline 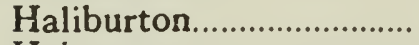 & \\
\hline & \\
\hline ….......... & \\
\hline Hur & \\
\hline & \\
\hline $\mathrm{Ke}$ & \\
\hline Lar & \\
\hline $\mathcal{L}$ & \\
\hline Lee & \\
\hline Addington .. & \\
\hline & \\
\hline & \\
\hline & \\
\hline $\mathrm{Mu}$ & \\
\hline & \\
\hline & \\
\hline No & \\
\hline ......... & \\
\hline & \\
\hline ound .... & \\
\hline & \\
\hline & \\
\hline igh & \\
\hline ......... & \\
\hline Pri & \\
\hline & \\
\hline & \\
\hline & \\
\hline ……........... & \\
\hline & \\
\hline & \\
\hline & \\
\hline 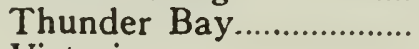 & \\
\hline ………............. & \\
\hline & \\
\hline & \\
\hline & \\
\hline & \\
\hline & \\
\hline
\end{tabular}

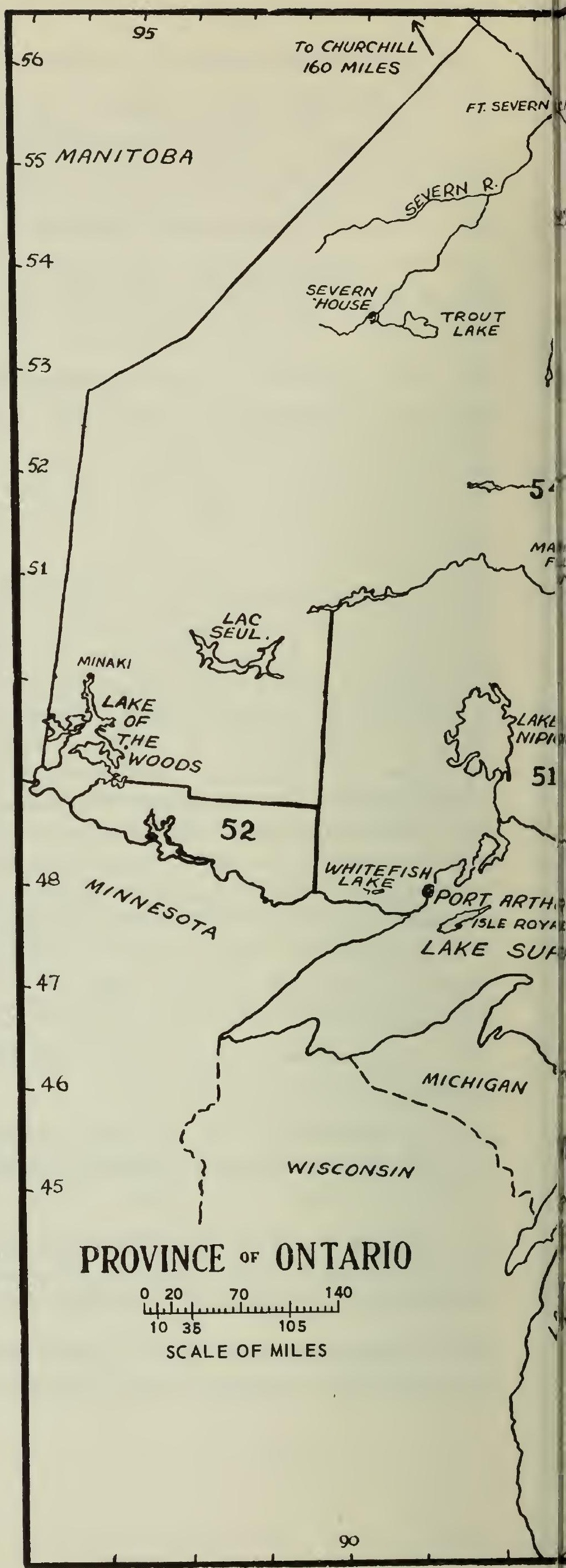


$45,46,47,48,49,51,53,54.0$ I *Aster acuminatus, *A. ciliolatus (A. lindleyanus), A. cordifolius, *A. ? johanensis (sub. A. longiflorus), A. macrophyllus, $*$ * puniceus, A. sagittifolius *A. simplex, Aster sp.; Epilobium angustifolium; *Erigeron philadelphicus; *Lactuca canadensis, *L. sativa; *Oenthera biennis; *Prenanthes? alba. II III *Carex backii, C. bebbii, C. brevior, C. cephalophora, C. chordorrhiza, ${ }^{*} C$. crawfordii, C. cristatella (C. cristata), C. disperma (C. tenella), C. foenea, C. festucacea, C. pensylvanica, C. rosea, C. scoparia, $C$. sparganioides, $C$. sprengelii, ${ }^{*} C$. stipata, C. tenera (C. straminea), ${ }^{*} C$. tribuloides, C. vulpinoidea, Carex sp.; Dulichium arundinaceum. In his treatment of this complex species (sub. P. extensicola) Arthur (1934) has created 10 varieties 7 of which are recorded from Ontario. The varietal combinations under P.dioicae, have not been formally made and therefore $P$. dioicae in this work embodies most of Arthur's varieties. Records of the aecial stage on Dirca palustris, treated under varietal rank by Arthur (op. cit.), are listed herein under the form genus Aecidium.

104. *P. drabae Rud. 1829. III Draba sp. TRTC 10567, 10568 Thunder Bay Dist. There are numerous specimens in DAOM from the N.W.T. and a report from Churchill, Manitoba, by Bisby et al. (1938). It is possible that this species occurs also in the regions bordering James and Hudson Bays.

105. P. eatoniae Arth. 1904 var. ranunculi Mains 1932. 2 DAOM, 2 DEARN, 1 PUR, 5 TRTC. Range 1, 3, 4, 5, 11, 17, 18, 19, 40. 0 I Ranunculus abortivus. II III Sphenopholis intermedia (sub. S. pallens). Although not yet known from Ontario, aecia are known to occur also on Myosotis (Boraginaceae).

106. P. eleocharidis Arth. 1884. I DAOM, 5 DEARN, 5 PUR, 12 TRTC. Range $3,4,5,17,19,25,27,40,47$. O I Eupatorium perfoliatum, E. purpureum, ${ }^{*} E$. rugosum (E. urticaefolium). II III Eleocharis palustris, Eleocharis sp. on culms. Eupatorium rugosum also supports Puccinia tenuis an aut-opsis rust having all spore forms smaller, and in which telia often accompany aecia.

107. P. ellisiana Thuem. 1878. O I Viola sp. DAOM (Canadian Fungi 15) Thunder Bay Dist. II III Andropogon gerardi DEARN 3340 Middlesex Co., *A. scoparius TRTC 6781 Bruce Co. The collection of aecia from Thunder Bay District is very old (1884) and in rather poor condition. Viola spp. support a number of other rusts, the most commonly encountered is $P$. violae. Andropogon is also infected with a number of pucciniaceous rust species.

108. P. emaculata Schw. 1832. I DAOM, 2 DEARN, 2 PUR. Range 2, 4, 5, 16, 40, $O$ I not known. II III Panicum capillare. Very similar to $P$. panici but separated on slight differences in spore size.

109. *P. epilobii DC. 1815. III Epilobium palustre var. grammadophyllum DAOM 25425 Thunder Bay Dist. This is a new host and a good range extension, the rust having been reported by Arthur (1934) from only 3 localities in North America. Other recent range extension records in DAOM are from St. Anthony, Nfld., Prince George, B.C., and Long I., Hudson Bay. 
110. P. erigeniae (Orton) Arth. 1921. O I III Erigenia bulbosa DEARN 80(d), 1518 , 1519, Middlesex Co. The host is found only in southwestern Ontario. The rust closely resembles $P$. pimpinellae in having similar spore features and by its occurrence on a related umbellifer.

111. *F. traseri Arth. 1915. III Hieracium scabrum TRTC 1059, 9022 Nipissing Dist. II spores (fide Arthur) are occasionally found amongst III spores; the latter have firm rather than deciduous pedicels and are smooth-walled and generally narrower than teliospores of $P$. hieracii, also a parasite of $H$. scabrum.

112. P. gentianae (Strauss) Roehling 1813. 2 DAOM 1 DEARN, 3 PUR 1 TRTC. Range 5, 8, 40. 0 I II III Gentiana andrewsii. Aecia were not present on the above specimens which were all collected in late summer.

113. P. graminis Pers. 1801. $87 \mathrm{DAOM}_{t} 17$ DEARN, 20 PUR, 34 TRTC. Range $1,2,3,5,7,8,9,11,17,18,19,21,23,25,27,28,30,34,38,40,41,43,45$, $47,48,49,53,54$. 0 I Berberis vulgaris and the following named specimens in the Dominion Arboretum and Botanic Garden, Ottawa: B. emarginata, B. laxifolia, $B$. ? macrophylla. II III *Agropyron griffithsii, A. repens; *Agrostis alba, Alopecurus geniculatus var. aristulatus, $* A$ pratensis, A. serawchanicus; ${ }^{*}$ Ammophila breviligulata; *Avena brevis, A. ? chinensis, *A. fatua, *A. ? Ludoviciana, A. sativa, *A. sterilis, *A. strigosus, Avena sp.; Briza minor; Cinna arundinacea; *Dactylis glomerata; *Elymus virginicus; *Festuca elatior; Glyceria grandis; *Hordeum jubatum, ${ }^{*} H$. vulgare; Nilium effusum; Phleum pratense; ${ }^{*}$ Poa compressa, *P. pratensis; Secale cereale; Triticum aestivum. Severe, province-wide outbreaks have not occurred in Ontario to the extent that they occur in the Prairie Provinces. In the prairies, inoculum originating from the southern states arrives during the summer in the form of wind-borne urediniospores. In Ontario windborne inoculum from outside the province may account for scattered rust incidence, but sometimes severe, localized outbreaks arise from aeciospore infection and are dependent on association with barberry. The acreage sown to oats in Ontario is practically double that sown to wheat and it would seem that basic requirements for establishing local epiphytotics occur more frequently between barberry and oats than between barberry and wheat. Numerous investigations have been conducted in the problems arising from infection of cereals by $P$. graminis. Our knowledge of this parasitic disease, so highly important in the Canadian wheatproducing economy, has been summerized in a popular account by J.H. Craigie (Canada Department of Agriculture Bulletin 666 (revised 1957)).

114. *P. haleniae Arth. \& Holw. 1887. 3 TRTC. Range 13, 25, 46, 54 III Gentiana amarella, *Halenia deflexa. Bisby et al. (1938) record the rust on Gentiana from Minaki in Kenora Dist.

115. P. helianthi Schw. 1822. 4 DAOM, 6 DEARN, 3 PUR, 7 TRTC. Range 2, $5,6,11,40,47,48,53$. 0 I II III Helianthus annuus, *H. decapetalus, H. giganteus, $H$. laetiflorus var. rigidus ( $H$. rigidus), *H. maximiliani, $H$. strumosus, $H$. tuberosus, Helianthus sp. In some years in Manitoba, sunflower rust results in considerable loss of the seed crop. 
116. P. heveherae (Schw.) Diet. 1891 var. heucherae. 4 DAOM, 3 DEARN, 2 PUR, 9 TRTC. Range 4, 5, 7, 8, 19, 40, 51. III Mitella diphylla, M. nuda; Tiarella cordifolia.

117. P. heucherae (Schw.) Diet. 1891 var. saxifragae (Schlect.) Savile 1954. [ 1 DACM], 3 TRTC. Range 19, 51, 54 and [Great Whale River, Que.]. III Heuchera richardsonii, [Saxifraga rivularis], S. virginiensis. The treatment here follows Savile's (1954) revision of the microcyclic rusts of Saxifragaceae.

118. P. hieracii (Roehling) Martius 1817. 19 DAOM, 4 DEARN, 7 PUR, 20 TRTC. Range $1,5,7,8,11,16,17,18,19,26,40,45,47,48,49,53,54$ and [Great Whale River, Que.]. 0 I II III Cichorium intybus, Hieracium canadense, *H. scabrum; Leontodon sp.; *Taraxacum ceratophorum, *T. erythrospermum, *T. latilobum, T. officinale (T. vulgare).

119. P. hordei Otth. 1871 (P. anomala Rostr. 1873). 4 DAOM, I TRTC. Range 11, 17, 40. 0 I Ornithogalum spp. Known only from Europe. II III Hordeum vulgare. There are records of this rust from New Brunswick to Saskatchewan but infection is generally light and any losses negligible.

120. *P. hydrophylli Peck \& Clint. 1878. III Hydrophyllum virginianum DEARN 653 Middlesex Co.

121. P. investita Schw. 1832. O I III Gnaphalium macounii DEARN 2513 Middlesex Co. A phanerogamic specimen collected at the same time as the rust (20 Sept. 1897) is in DAO.

122. P. iridis Rab. 1844. 7 DAOM, I DEARN, 3 PUR, 8 TRTC. Range 5, 7, 8, 17, 19, 40, 47 and [Hull, Que.]. 0 I Not known in North America but reported from Siberia on Valeriana and from Norway on Urtica. II III Iris versicolor. Telia are not present on any of the above specimens even though collection dates range from July to October over a period of years. Arthur (1934) reports only the uredinial stage east of the Rocky Mountains.

123. *P. karelica Tranz. 1905. O I Trientalis americana DAOM 23947 Carleton Co. II III Carex paupercula TRTC 7293 Bruce Co., DAOM 23944 Carleton Co., and [DAOM 49815 Rupert House, Que.]. Tranzschel (1939) made this a subspecies of $P$. limosae and Hylander Jorstad and Nannfeldt (1953) treated it under $P$. caracina var. limosae.

124. P. lapsanae Fckl. 1860. 2 DAOM, I DEARN, I PUR. Range 11, ?19, 32, 40. 0 I II III Lapsana communis.

125. *P. liatridis (Årth. \& Fromme) Beth. ex Arth. 1934. 0 I Liatris aspera and L. cylindricea DEARN 8123 both from Lambton Co. II III Koeleria and Agrostis but not known in Ontario.

126. [*P. ligustici Ell. \& Ev. 1895. III Ligusticum scothicum DAOM 23605 Great Whale River, Que. At the above site, the rust was confined to one small colony 
where the host was abundant along a rocky shoreline.]

127. P. limosae Magn. 1877. 2 DAOM, 4 DEARN, 11 PUR. Range 5, 45, 47. O I Lysimachia thyrsifolia (Naumburgia t.). II III Carex arcta, C. crinita, C. limosa, * $C$. vesicaria. For the purposes of this work $P$. limosae is retained as a separate entity, but there is a close relationship with $P$. karelica.

128. P. linkii Klotzsch 1833. III *Viburnum edule (V. pauciflnrum) TRTC 10569, 19551 Thunder Bay Dist. Added field search will no doubt broaden the range of this species in Ontario. It is far better represented in DAOM from Quebec and Manitoba than from Ontario.

129. P. lobeliae Ger. ex Pk. 1873. I DEARN, I PUR, 4 TRTC. Range 5, 7, 8, 15, 43. III Lobelia siphilitica. $P$. lobeliae and $P$. campanulae were maintained as separate entities by Arthur (1934) primarily because they occurred on plants in different, although related, families. Fernald (1950) now treats the respective hosts in Campanulaceae. Should these rusts prove to be morphologically similar then the name $P$. campanulae Carm. ex Berk. 1836 has priority. P. campanulae (s. str.) is not known in Jntario.

130. P. ludovicianae Fahr. 1941 (segregate of $P$. absinthii DC. 1815). 0 II III *Artemesia ludoviciana TRTC 2200, Faull 8165 (TRTC) Nipissing District also reported (sub $P$. absinthii) by Bisby et al. (1938) from Kenora Dist. The segregation of this species is based on the presence of large, capitate, hyaline paraphyses in the uredinia. These structures are present in the material in TRTC. P. absinthii (s. str.) is antedated by $P$. tanaceti DC. 1805 and is not known to occur in Ontario. D.B.O. Savile (in conversation) is of the opinion that nearly every species of Artemesia and Tanacetum bears its own variety of $P$. tanaceti and that these do not merit specific rank.

131. P. magnusiana Koern. 1876. 2 DAOM, 3 DEARN. Range 1, 3, 6. 0 I Anemone cylindrica. II III Phragmites communis. II spore germ pores are numerous and scattered (cf. P. phragmitis).

132. P. malvacearum Bert. ex Mont. 1852. 22 DAOM, 3 DEARN, 7 PUR, 13 TRTC. Range $1,5,7,9,10,11,15,17,19,21,25,27,33,35,37,40,54$. III * Althaea armeniaca, A. ficifolia, A. rosea, Malva moschata, *M. neglecta, M. rotundifolia, (M. borealis), M. sylvestris.

133. P. mariae-wilsoniae Clint. 1873. 22 DAOM, 2 DEARN, 5 PUR, 16 TRTC. Range $1,4,5,8,9,11,19,25,26,40,41$ and [Gatineau area, Que.]. 0 I III Claytonia caroliniana, C. virginica. Endophyllum lacus-regis (q.v.) is also found on Claytonia. The two rusts are distinguished on aecial habit and aeciospore size as well as life cycle.

134. P. marylandica Lindr. 1901. 4 DAOM, I DEARN, I TRT. Range 27 and [Montreal, Que.]. 0 I II III *Sanicula marylandica. 
135. P. menthae Pers, 1801. 14 DAOM, 6 DEARN, 13 PUR, 20 TRTC. Range l, $3,4,5,8,11,15,19,25,26,30,47$ and [Gatineau area, Que.]. 0 I II III Mentha arvensis forma glabra, $M$. arvensis var. villosa (M. canadensis), $M$. spicata; Monarda didyma, M. fistulosa, M. fistulosa vor. mollis (M. mollis); Pycnanthemum flexuosum, P. virginianum; ${ }^{*}$ Satureja arkansana, S. vulgaris (Clinopodium vulgare). Aecia bullate, aeciospores coarsely verrucose (cf. $P$. angustata.)

136. P. mesomajalis Berk. \& Curt. ex Pk. 1873. 2 DAOM, 9 TRTC. Range 25. $47,48,51,54$. III Clintonia borealis.

137. *P. microsora Koern. ex Fckl. 1874. 4 DAOM, 4 TRTC. Range 40, 45, 47. 0 I unknown. II $\mathrm{II}^{2}$ III $*$ Carex retrorsa, ${ }^{*} C$. vesicaria, ${ }^{*} C$. vesicaria var. monile. Amphisori are abundant, teliospores occur only intermixed with amphispores $\left(\mathrm{II}^{2}\right)$. The latter function as normal urediniospores (II ${ }^{\mathrm{l}}$ ) but differ in morphology and are capable of overwintering.

138. [*P. millefolii Fckl. 1870. III *Achillea millefolium DAOM 23798, 23799, Great Whale River, Que. Hylander, Jorstad and Nannfeldt (1953) place this species in synonomy with $P$. asteris under $P$. cnicioleracei Pers. ex Desm.].

139. P. minutissima Arth. 1907. 3 DAOM, 9 DEARN, I PUR, 3 TRTC. Range $2,3,5,7,17,18,40$. 0 I Decodon verticillatus. II II Carex aquatilis (C. substricta), C. filiformis, C. lasiocarpa ${ }^{*} C$. leptalea. Aeciospores possess pore plugs as in $P$. dioicae and telial characters are similar to the latter also.

140. P. monoica Arth. 1912. O I Arabis lyrata, DEARN 3433 Lambton Co. II III Koeleria, Trisetum, Stipa not known in Ontario.

141. P. obscura Schroet. ex Pass. 1877. O I Bellis perennis known in Europe but not reported from North America although the host is cultivated in Ontario and has been found as an 'escape' in the Toronto area. II III Luzula acuminata var. carolinae ( $L$. carolinae) DAOM 59447, DEARN 1862 and 7 records in PUR, all from Middlesex Co.

142. P. obtecta Peck 1873. I DAOM 3 DEARN, 4 TRTC. Range 5, 19, 25, 26, 27, 46. 0 III Bidens sp. II III Scirpus americanus, *S. acutus, S. cyperinus, S. validus, Scirpus sp.

143. P. orticula Peck. \& Clint. 1879. 3 DAOM, 3 DEARN, 11 TRTC. Range 3, $11,19,27,32,40,43.0$ I II IIl *Prenanthes alba (Nabalus a.), *P. altissima, Prenanthes sp.

144. P. ornata Arth. \& Holw. 1887. 3 TRTC. Range 19, 22. III *Rumex orbiculatus ( $R$. britannica), $R$. verticillatus, Rumex $\mathrm{sp}$.

145. [*P. oxalidis Diet. \& Ell. 1895. 3 DAOM. Range 40. O I Mahonia repens not known in Ontorio. II III $*$ Oxalis corymbosa (O. martiana), $O$. rubra. The natural range of this rust is in southern United States. The specimens (II only) 
in DAOM were taken from a greenhouse overrun with Oxalis; apparently the rust had been introduced with the imported Oxalis].

146. P. panici Diet. 1895. O I Euphorbia spp. No Ontario records. II III *Panicum virgatum DAOM 19995, DEARN 3176 Norfolk Co., TRTC 6779 Bruce Co. The slightly larger urediniospore size is used by Arthur (1934) to distinguish this species from $P$. emaculata.

147. [P. pazschei Diet. 1891. III Saxifraga cotyledon TRTC 9183 and S. lingulata var. lantoscana DAOM 2015 (TRTC 5787) both from the greenhouses of the Department of Botany, University of Toronto. For varietal differences see Savile (1954)].

148. P. phragmitis (Schum.) Koern. 1876. 8 DAOM. Range 3, 39. 0 I *Polygonum pensylvanicum, *P. lapathifloium. II III Phragmitis communis. The 0 I hosts Rheum rhaponticum and Rumex spp. listed by Arthur (1934) have not been found supporting this rust in Ontario. Field association of Polygonum and Phragmitis where the latter was heavily rusted suggested the possibility of the former being an alternate host. Aecia were found on young Polygonum leaves and were used to infect isolated plants of the grass. Telia overwintered in the field were used to inoculate, successfully, the above Polygonum spp., which had been started in the greenhouse from seed. The aecial stage is found on leaves and stems of young plants ( $2-4$ inches) only; badly infected seedlings die, or the infected leaves fall, leaving no evidence that the Polygonum is the alternate host.

149. P. physalidis Peck. 1879. 4 DAOM, I DEARN, I PUR. Range 2, 40. III Physalidis heterophylla. Infection is systemic. (cf. Aecidium physalidis).

150. *P. physostegiae Peck \& Clint. 1878. 3 TRTC. Range 11, 19. IIl Physostegia virginiana. Telia systemic.

151. P. pimpinellae (Strauss) Roehling 1813. 4 DAOM, I DEARN, 5 PUR, 10 TRTC. Range 1, 2, 4, 5, 8, 11, 19, 27, 30, 40, 48 and [Gatineau area, Que.]. O I II III Osmorhiza claytoni, O. longistylis, Osmorhiza sp. Chaerophyllum, closely related to Osmorhiza, has been found rusted in the state of Pennsylvania and it may be found carrying this autoecious species in southern Ontario.

152. *Puccinia plumbaria Pk. 1881. 4 DAOM. Range Lanark Co. O I III Phlax divaricata. Pycnia and aecia systemic, telia localized. The host is known to occur throughout southern Ontario in rocky, deciduous, hardwoods. Rusted plants were most conspicuous when aecia were fully mature about the end of May 1959 in the vicinity of Ottawa.

153. $P$. poae-nemoralis Otth 1871 ( $P$. poae-sudeticae Westend. 1869). 10 DAOM, 1 DEARN, 7 TRTC. Range 5, 8, 9, 19,40,47, and [Great Whale River, Que.]. 0 I unknown. II III *[Agrostis borealis]; *Poa annua, *[P. arctica], *P. compressa, $P$. pratensis, $* P$. palustris, Poa sp.; *[Trisetum spicatum]. Telia were absent from all of the Ontario collections. The presence of capitate paraphyses in the 
uredinia distinguished this species from $P$. poarum. The latter is not known to occur in Untario.

154. P. podophylli Schw. 1822. 16 DAOM, 4 DEARN, 4 PUR, 20 TRTC. Range $1,2,3,4,5,7,8,10,11,12,13,17,19,27,31,33.0$ I III Podophyllum peltatum. Basidiopsore infection may give rise to pycnia and aecia, to an association of aecia with telia, or to telia alone. Jackson (1931) cites this species as an example of a rust exhibiting an unstable life cycle, being in transition from an opsis- to a micro-form species.

155. P. polygoni-amphibii Pers. 1801. 17 DAOM, 9 DEARN, 7 PUR, 10 TRTC. Range $1,2,3,5,8,16,17,19,25,32,40,45,47.0$ I Geranium maculatum. II III Polygonum amphibium, $P$. coccineum ( $P$. muhlenbergii), $P$. convolvulus, *P. cristatum, $P$. hydropiperoides, $P$. lapathifolium, Polygonum sp. * Tovara virginiana (Polygonum virginianum). On the basis of the position of urediniospore germ pores and on the gross features of telia, Arthur (1934) has recognized three varieties. All three are recorded from Ontario.

156. *P. porphyrogenita Curt. ex Theum. 1876. 4 DAOM, 12 TRTC. Range 47, 51. III Cornus canadensis. Mesospores occasionally occur amongst normal two-celled teliospores.

157. *[Puccinia praegracilis Arth. var. connersii Savile 1951. O I Habenaria dilatata DAOM 23447 Great Whale River, Que. II III Deschampsia atropurpurea DAOM 23446 Great Whale River, Que. The appearance of the coronate teliospores caused Arthur to relegate this species, which he first described in 1907, to synonomy under $P$. coronata. Differences in spore characters plus widely different aecial hosts (cf. P. coronata) and lack of pycnia led Savile to erect a new species in 1950 and later (1951) to provide the above varietal combination.]

158. [P. pulsatillae Kalchb. 1865. III Anemone parviflora DAOM 23896 Great Whale River, Que. Alpine species of Anemone and Ranunculus in the barren regions of Ontario bordering Hudson Bay are expected to bear this rust.]

159. P. punctata Link 1815. 3 DAOM, 2 DEARN, 1 PUR, 6 TRTC. Range 5, 12, 17. 19, 40, 48. 0 I II III Galium asprellum, ${ }^{*} G$. palustre, Galium spp. Telia chiefly epiphyllous (cf. P. rubefaciens).

160. *P. punctata Link var. troglodytes (Lindr.) Arth. 1934. 0 I unknown II III Galium triflorum TRTC 12071 Brant Co., DAOM 63884 Lanark Co., TRTC 1443, 2870 Nipissing Dist.

161. P. punctiformis (Strauss) Roehling 1813 (P. obtegens Tul.). 13 DAOM, 1 DEARN, 1 PUR, 10 TRTC. Range 5, 8, 11, 17, 19, 30, 40, 42, 45, 47, 51, 54. 0 II III Cirsium arvense. Pycnia and uredinia hypophyllous and systemic, pore of teliospore basal cell depressed. (cf. P. cnici 0 II hypophyllous, not systemic, pore of teliospore basal cell located at septum; and cf. P. calcitrapae 0 II epiphyllous, not systemic, pore of teliospore basal cell depressed). 
162. P. pygmaea Eriks. 1895. O I Berberis sp. Europe, not known in North America. II III Oryzopsis asperifolia, PUR 21683 Middlesex Co., Oryzopsis sp. TRTC 8175 Nipissing Dist. The presence of numerous capitate paraphyses in the uredinia is an aid in identifying this rust. $P$. substerilis ( $P$. scaber) and $P$. burnettii, also occurring on Oryzopsis, are reported only from western North America. They are not known to have uredinial paraphyses.

163. P. pyrolae Cooke 1872. 3 DAOM, 1 DEARN, 3 PUR, 14 TRTC. Range 5, 7, $8,19,25,26,27,33,41,47,48$. III Polygala paucifolia.

164. *P. recedens Syd. 1902. III Senecio aureus TRTC 4678, 9529 York Co.

165. P. recondita Rob. ex Desm. 1857 ( $P$. rubigo-vera Wint.). 28DAOM,11 DEARN, 15 PUR, 53 TRTC. Range 1, 2, 3, 4, 5, 8, 11, 15, 16, 17, 19, 20, 21, 25, 27, 29, $34,36,40,41,45,47,48,49,51$ and [Gatineau area, Que.]. 0 I Actaea pachypoda *[A. rubra]; Anemone cylindrica, *A. multifida (A. hudsonia), A. quinquefolia, *A. virginiana; ${ }^{*}$ Cimicifuga racemosa; *Clematis verticillaris, C. virginiana; Impatiens capensis, I. pallida, Impatiens spp.; Lycopsis arvensis; *Ranunculus acris; *Thalictrum dasycarpum, *T. polygamum. Aecia yellow, in groups, finely lacerated (cf. Tranzschelia pruni-spinosae). II III Agropyron repens; *Alopecurus pratensis; Bromus ciliatus, B. latiglumus, B. purgans; Elymus virginicus; Secale cereale; Triticum aestivum. Pycnia and aecia are known on Ranunculaceae and Balsaminaceae in Ontario; elsewhere in North America the 0 I stages are reported on Boraginaceae and Hydrophyllaceae. The varieties that Arthur (1934) recognizes under $P$. rubigo-vera have not as yet been validly set up under $P$. recondita and records of them are therefore lumped under the latter binomial. In some years leaf rust of wheat causes considerable reduction in yield. Sulphur dusting of test plots in Manitoba showed this loss to be $4-20 \%$ (Canadian Plant Disease Survey 1942). Losses are less conspicuous in Ontario than in the prairies where the average yearly acreage sown to wheat is approximately ten times that sown in Ontario.

166. *P. ribis DC. 1805. III Ribes triste TRTC 2815 Nipissing Dist., DAOM 23525 Cochrane Dist.

167. *P. rubefaciens Johans. 1886. III Galium boreale L. (s. lat.) DAOM 49962, 49976 Kenora Dist. Common in Western Canada but apparently rare in Ontario. Telia hypophyllous.

168. P. sessilis Schneid. ex Schroet. 1870. 3 DAOM, 1 DEARN, 5 PUR, 4 TRTC. Range 5, 8, 21, 25, 26, 34, 43, 48. 0 I *Erythronium americanum; *Iris versicolor; Smilacina stellata. II III Phalaris arundinacea.

169. P. seymouriana Arth. 1902. O I [Cephalanthus occidentalis Ile Perrot, Que., known also on A pocynum and Asclepias spp.] not known in Ontario. II III Spartina pectinata (S. michauxiana) PUR 22723 Point Abino, Welland Co., 28 August 1896. The specimen has not been examined. 
170. *P. silphii Schw. 1832. III Silphium perfoliatum DEARN 1978 Niddlesex Co.

171. P. sorghi Schw. 1832. 8 DAOM, 1 DEARN, I PUR, 6 TRTC. Range 1, 5, $8,11,17,19,21,40,53.0$ I Oxalis spp. No Ontario collections. II III Zea mays. Although fairly common and widespread in the province, rust is not known to cause serious damage to the corn crop.

172. *P. sparganioides. Ellis \& Barth. 1896 (P. peridermiospora (Ell. \& Tr.). Arth.) 4 DAOM, 4 DEARN, 2 TRTC. Range 2, 40, 45, 48, and [Gatineau and Montreal areas, Que.]. 0 I Fraxinus americanus, Fraxinus sp. II III Spartina pectinata (S. michauxiana), Spartina sp.

173. P. sporoboli Arth. 1884. 4 DAOM, 2 DEARN, 6 TRTC. Range 3, 25. 0 I *Smilacina stellata. II III Calamovilfa longifolia. All specimens were collected at beach areas along the east shore of Lake Huron. Rusted Smilacina (DAOM) was collected in May 1955 growing intermixed with Calamovilfa that bore abundant overwintered telia. Away from Calamovilfa the Smilacina was healthy. In August fresh uredinia and telia were abundant on the grass at this site. H.C. Greene (in litt.) and G.B. Cummins have recently found that much of the material on Calamovilfa passing as $P$. amphigena is actually $P$. sporoboli, distinguished by its nearly basal urediniospore germ pores. All specimens in DAOM from Alberta and Saskatchewan in which any urediniospores, which are usually scarce, could be found proved to be $P$. sporoboli, and $P$. amphigena may be absent from Canada.

174. *P. tenvis Burr. 1884. O I III Eupatorium rugosum (E. urticaefolium) TRTC 17158 Halton Co. Aecia and telia are present in the single TRTC specimen. Teliospores form in oval, subepidermal locules delimited by rectangular cells (? paraphyses) $16.0-27.0 \times 3.0-8.0 \mu$. arising from the periphery of the mycelium which gives rise to the spores.

175. *P. thlaspeos Schub. 1823 (P. holboellii (Hornem.) Rostr.). 3 DAOM, 1 TRTC. Range 5, 54 and [Old Factory and Great Whale River, Que.]. 0 III Arabis arenicola, Arabis sp., *[Draba incana]. Infection is systemic.

176. *P. tumipides Peck 1885. 0 II III Lycium halimifolium TRTC 5675, 17177 Lincoln Co., DAOM 61825 Peel Co., TRTC 23238 Simcoe Co. These specimens were all collected in late summer and do not bear pycnia or primary uredinia.

177. *P. virgae-aureae (DC..) Lib. 1837. (P. virgaureae (DC.) Lib.). III Solidago lanceolata DAOM Carleton Co.

178. $P$. vincae Berk. in Smith 1836. 3 DAOM, I DEARN, l PUR. Range 5, 17, 19, 22, 40. 0 II III Vinca major. Most of the Ontario collections were obtained from pereiwinkles growing in the greenhouse; just occasionally is the rust found on plants growing outdoors. Aecia are described as uredinoid, but none were present in the Ontario specimens.

179. P. violae (Schum.) DC. 1815. 17 DAOM, 4 DEARN, 8 PUR, 16 TRTC. 
Range $1,2,3,5,8,17,19,20,25,26,40,42,47,48,51$ and [Gatineau area and Great Whale River, Que.]. 0 I II III *Viola adunca var. minor, *V. blanda, $* V$. canadensis, *V. conspersa, ${ }^{*} V$. ? nephrophylla, *V. pallens, V. pensylvanica $(V$. eriocarpa), V. pubescens, *V. selkirkii, V. septentrionalis, $V$. soraria, Viola spp.

180. $P$. waldsteiniae Curt. ex Pk. 1873. I DAOM, I DEARN, I TRTC. Range 19, 47, 48 (?49). III Waldsteinia fragarioides. Found sparingly in Ontario as well as in the rest of the known range in North America.

181. P. windsoriae Schw. 1832. 0 I Ptelea trifoliata not known in Ontario. II III Triodia flava PUR (DEARN cult. 10113) Lake Huron Ont., 25 May 1912. Duplicate material of this record was not found in the Dearness collection of Uredinales and the specimen in PUR has not been examined.

182. P. xanthii Schw. 1822. 4 DAOM, 6 DEARN, 3 PUR, 2 TRTC. Range 1, 3, 4, 5, 8, 11, 16, 19. III Ambrosia trifida; Xanthium chinense, *X. echinatum, $* X$. italicum, *X. strumarium.

\section{PUCCINIASTRUM}

Where known, pycnia and aecia occur on needles of Abies, Picea and Tsuga and uredinia and telia parasitize members of various plant families notably Roascecre and Ericaceae. Hiratsuka $(1936,1958)$ believes that the location of the teliospores within the host is sufficient grounds to maintain Thecospora and Calyptospora as separate genera. These are treated as subgenera of Pucciniastrum by Arthur (1934). The latter treatment is followed in this work because in this writer's opinion generic separations should be based on adequate morphological differences and except for the location of the teliospore germ pores there appears to be no morphological differences.

183. P. agrimoniae (Diet.) Tranz. 1895. 6 DAOM, 2 DEARN, 1 PUR, 5 TRTC. Range 2, 5, 40,47,51, 54 and [Gatineau area, Que.]. 0 I Unknown, possibly Tsuga. II III *Agrimonia gryposepala, A. pubescens (A. mollis), *A. striata.

184. P. americanum (Farl.) Arth. 1920. 9 DAOM, 3 DEARN, 5 PUR, 18 TRTC. Range 5, 7, 8, 11, 17, 18, 39, 44, 45, 47, 50 and [Gatineau area, Que.]. 0 I Picea glauca (P. canadensis). II III Rubus idaeus var. aculeatissimus, and var. strigosus, [*R. neglectus], Rubus sp.

185. P. arcticum Tranz. 1895. I DAOM, 9 TRTC. Range 7, 8, 19, 40, 47. 0 I Picea glauca ( $P$. canadensis) no Cnt. collections. II III Rubus pubescens.

186. P. epilobii Otth 1861 (P. pustulatum (Pers.) Diet.). 20 DAOM, 4 DEARN, 2 PUR, 18 TRTC. Range 5, 8, 10, 19, 31, 32, 40,47, 48, 51, 54, and [Rupert House and Great Whale River, Que.]. 0 I Abies balsamea. II III Epilobium angustifolium, E. coloratum, E. glandulosum var. adenocaulon and var. occidentale, E. hirsutum, [E. palustre], E. strictum, Epilobium spp. Also Clarkia elegans by inoculation from $E$. hirsutum. 
187. P. goeppertianum (Kuehn.) Kleb. 1904. 5 DAOM, 12 TRTC. Range 47, 51, 54. O I *Abies balsamea. III Vaccinium angustifolium ( $V$. pensylvanicum), $V$. vitis-ideae, Vaccinium spp. The conspicuous swelling of infected twigs and stems of blueberry permits immediate recognition of this rust.

188. *P. gutfatum (Schroet.) Hyl., Jorst., Nannf. 1953 (P. galii (Lk.) Fischer). 0 I Unknown. II III Galium triflorum TRTC 19556, 20406 Nipissing Dist. These are the only Ontario collections. Arthur 1934 indicates this species to be sporadic in eastern North America (cf. Puccinia rubefaciens).

189. P. potentillae Korn. 1900. 4 DAOM, I DEARN, I PUR, 6 TRTC. Range 47, 48, 49, 51, and [Great Whale River, Que.]. 0 I Unknown. II III Potentilla tridentata.

190. P. pyrolae Diet. ex Arth. 1907. 5 DAOM, 3 DEARN, 2 PUR, 6 TRTC. Range 4, 25, 47, 348, and [Rupert House and Great Whale River, Que.]. 0 I Unknown. II III Pyrola elliptica [*P. minor], P. secunda. Hypophyllous and localized. It is expected that where pyrolas occur along Hudson Bay the rust parasite will be present also. (cf. Chrysomyxa pirolata).

191. *P. sparsum (Wint.) E. Fischer 1904. 0 I Picea abies known in Europe. II III * Arctostaphylos rubra DAOM 23990 Lake River, Kenora Dist. ( $\left.54^{\circ} 20^{\prime} \mathrm{N}\right)$, on the west coast of James Bay. Although P. abies (Norway spruce) is planted in Ontario, it is not likely that infection of the Arctostaphylos originated from such cultivated trees. In the above region Picea glauca and $P$. mariana are common and either might be an aecial host.

192. P. vaccinii (Wint.) Jorstad 1951 (P. myrtilli (Schum.) Arth.). 2 DAOM, 3 DEARN, 2 PUR, 7 TRTC. Range 5, 7, 47, 48 and [Norway Bay, Que.]. 0 I *Tsuga canadensis, aecia hypophyllous, conspicuous by a white cylindrical peridium (cf. Melampsora abietis-canadensis). II III Vaccinium angustifolium ( . pensylvanicum), V. corymbosum, Vaccinium $\mathrm{sp}$.

\section{TRANZSCHELIA}

Teliospores are two-celled and in general appearance resemble those of Puccinia. Separation from the latter is maintained because teliospore pedicels are fused together and arise from a common base. This condition is directly opposite to that found in the genus Puccinia.

193. T. anemones (Pers.) Nannf. 1939 (T. fusca Diet., T. thalictri (Chev.)Diet.). 8 DAOM, 5 DEARN, 5 PUR, 10 TRTC. Range 1, 3, 5, 6, 8, 10, 11, 17, 18, 19, 40, 53, and [Gatineau area, Que.]. 0 III Anemone quinquefolia; *Thalictrum dioicum, T. polygamum.

194. T. pruni-spinosae (Pers.) Diet. 1922. 5 DAOM, 9 DEARN, 5 PUR, 3 TRTC. Range 3,5, 8, 16, 26 and [Ile Perrot, Que.]. O I Anemone quinquefolia, Hepatica acutiloba. Aecia are brown, hypophyllous, scattered, and the peridia open widely and generally split into 4 lobes. II III *Prunus americana, ${ }^{*} P$. persica, $* P$. serotina, $P$. virginiana. 


\section{UREDINOPSIS}

Like Milesia (q.v.), Uredinopsis causes infection of needles of balsom fir ( $O$ I), then alternates to the fronds of various ferns (II III). There are two types of urediniospores, the ordinary type (II $\left.{ }^{1}\right)$ and amphispores $\left(\mathrm{II}^{2}\right)$. Except for the thicker wall of $\left(\mathrm{II}^{2}\right)$, the latter resemble the former but they function, by means of this thicker wall and a required dormant period, to overwinter the fungus and to reinfect the fern the following spring. The treatment here follows Faull's monograph of the genus (1938) and therefore recognizes seven species that occur in Ontario. Faull did much of his culture work at Timagimi, Nipissing Dist., and some of this material is located at the University of Toronto.

195. U. americana Syd. 1903 (U. mirabilis (Peck) Magn. 1904). 8 DAOM, 5 DEARN, 2 PUR, 17 TRTC. Range 2, 5, 6, 8, 11, 13, 15, 17, 19, 21, 38, 41, 43, 47, 48, 54 and [Ile Perrot and Gatineau area, Que.]. 0 I Abies balsamea hypophyllous on needles of current season. II $^{1}$ II $^{2}$ III Onoclea sensibilis hypophyllous (amphigenous). Records from Kenor $\propto$ Dist., Norfolk and Wellington Co. were obtained from Bisby et al. (1938) and Faull (1938) respectively.

196. U. atkinsonii Magnus 1904. 3 DEARN, 2 PUR, 2 TRTC. Range 2, 5, 8, 11 , 19. O I Abies balsamea hypophyllous on needles of current season, no records from Ontario. II $^{1}$ II $^{2}$ III Dryopteris thelypteris hypophyllous (amphigenous).

197. U. ceratophora Faull 1938. 2 PUR, I TRTC. Range 17, 19, 27, 47. O I Abies balsamea hypophyllous on needles of current season. $\mathrm{II}^{1} \mathrm{II}^{2}$ III Cystopteris bulbifera hypophyllous (amphigenous). This species was segregated by Faull (1938) from U. atkinsonii Magn., U. copelandii Syd., and U. struthiopteridis Störmer.

198. U. longimucronata Faull 1938. I DAOM, 14 TRTC. Range 11, 17, 19, 47 and [Gatineau area, Que.]. 0 I Abies balsamea hypophyllous on needles of current season. II ${ }^{1}$ II $^{2}$ III Athyrium felix-femina hypophyllous (amphigenous). Like the previous species, this is a segregate from a number of other entities (Faull 1938).

199. U. osmundae Magn. 1904. 6 DAOM, 2 DEARN, 23 TRTC. Range 5, 19, 40. $43,45,47,51$. O I Abies balsamea hypophyllous on needles of current season. II III Osmunda cinamomea, $O$. claytoniana, ${ }^{*} O$. regalis, Osmunda sp. hypophyllous (amphigenous). Amphispores are absent.

200. U. phegopteridis Arth. 1907. 3 DAOM, 3 TRTC. Range 45, 47, 51. 0 I Abies balsamea hypophyllous on needles of current season. II III Dryopteris disjuncta (D. linneana, Phegopteris dryopteris) hypophyllous (amphigenous). Amphispores are absent.

201. U. struthiopteridis Störmer ex Diet. 1895. I DAOM, 2 TRTC. Range 47. 0 [ Abies balsamea hypophyllous on needles of current season. $\mathrm{II}^{1} \mathrm{II}^{2}$ III Matteuccia struthiopteris (Pteretis pensylvanica) hypophyllous (amphigenous). Bisby et al. (1938) report all stages from Rennie, Manitoba, and it is likely that the species occurs in adjacent parts of Ontario. 


\section{UREDO}

In this form-genus are included those rusts that possess uredinia but have no known telia connection.

202. [*Uredo behnickiana P. Henn. 1905. II Oncidium longipes TRTC 30,004 obtained from potted plants in the greenhouses of the University of Toronto. The orchid on which this tropical rust was found had been received from Brazil.]

\section{UROMYCES}

Rusts of the genus Uromyces are identified by their single-celled teliospores. In ull other respects they resemble Puccinia.

203. *U. acuminatus Arth. 1883. O I Lysimachia ciliata (Steironema ciliatum) TRTC 3320 Brant Co. II III Spartina spp. No collections from Ontario.

204. U. americanus Speg. 1909. (segregate of U. scirpi Burr.) O I unknown. II III Scirpus validus DEARN 3472 Lambton Co. The subepidermal, loculate nature of the telia distinguishes this species from $U$. lineolatus. For other differences see description in Mycologia 27:610-612. 1935.

205. U. ari-triphylli (Schw.) Seeler 1942 (U. caladii (Schw.). Farl.).14 DAOM, 4 DEARN, 5 PUR, 27 TRTC. Range 1, 2, 4, 5, 7, 8, 10, 11, 14, 15, 18, 19, 23, 25, 26, 40 and [Gatineau area, Que.]. 0 I II III Arisaema atrorubens, A.dracontium, A. triphyllum; *Peltandra virginica. O I systemic and conspicuous whereas II III are localized and more difficult to discern in the field.

206 [*U. armeriae Lev. 1867 (U. limonii (DC.) Lev. var. armeriae (Schl.) Arth.). ssp. hudsonicus Savile and Conners 1951. O I II III Armeria maritima var. labradorica DAOM 23450, 23451 Great Whale River, Que.]

207. U. asclepiadis Cke. 1877. 5 DAOM, I DEARN. Range 2, 4, 5, 11. 0 I II III Asclepias incarnata, A. syriaca. Pycnia and aecia have not been found in Ontario and indeed pycnia are unknown and the presence of aecia is uncertain. The species is considered to be autoecious.

208. U. coloradensis Ell. and Ev. 1893. O I III Vicia americana (V. oregana) Can. Fungi 4 in DAOM, Thunder Bay Dist., DAOM 23966, 40169 Kenora Dist. Pycnia and aecia are systemic; teliospores are verrucose and readily distinguished from the smooth, long-pedicelled spores of $U$. fabae which also occurs on $V$. americana. Three varieties are recognized in North America one of which, var. campester Arth., ranges from Ontario to the southern United States.

209. U. dianthi (Pers.) Niessl. 1872 (U. caryophyllinus Wint.).7 DAOM, I DEARN, 3 PUR, 3 TRTC. Range 5, 10, 11, 18, 19, 40 and [Aylmer and Montreal, Que.]. U I Euphorbia gerardiana known only in Europe. II III Dianthus caryophyllus. Rust occurs on carnations grown under glass and in the garden; there is some indication of varietal resistance in the host. 
210. U. euphorbiae Cke. \& Pk. in Pk. 1873 (U. proeminens Pass.).15 DAOM, 4 DEARN, 2 PUR, 10 TRTC. Range 1, 4, 5, 8, 12, 19, 22, 24, 32, 40 and [Gatineau area Que.]. $O$ I II III Euphorbia dentata, ${ }^{*} E$. glyptosperma, E. humistrata, ${ }^{*} E$. maculata, *E. serpyllifolia, E. vermiculata (E. hirsuta), Euphorbia spp. In his treatment of this species under U. proeminens, Arthur (1934) recognized four varieties, three of which are known from Ontario: var. typica, var. euphorbiicola, var. poinsettiae. Arthur's varietal distinctions depended mainly on differences in the hosts; however, the latter have since been shown to have a much closer relationship and Fernald (1950) has placed them all in the genus Euphorbia.

211. U. fabae (Grev.) DBy ex Cke. 1879. 17 DAON, 2 DEARN, 4 PUR, 9 TRTC. Range 4, 5, 17, 18, 19, 20, 21, 35,40,41,45,47, 50, 51. O I II III Lathyrus ochroleucus, L. palustris var. myrtifolius, (L. myrtifolius); *Pisum sativum; *Vicia cracca *Vicia sp. The race on Vicia cracca attacks Pisum sativum but apparently not Lathyrus spp.

212. *U. geranii (DC.) Lev. 1847. 11 DAOM, 3 TRTC. Range 35, 40. 0 I II III Geranium albiflorum, $G$. anemonaefolium, $G$. platypetalum, $G$. pratense, $G$. sylvaticum, Geranium sp. All specimens are recorded on cultivated Geranium.

213. [*U. halstedii de Toni in Sacc. 1888. 0 I Trillium erectum DAOM 18681, T. grandiflorum DEARN 7470. Both collections are from Ile Perrot, Que. II III Leersia spp. but not known from Ontario or Quebec.]

214. *U. hedysari-obscuri (DC.) Lev. 1849. 3 DAOM, I TRTC. Range 51, 53, 54 and [Harricanaw River, Que.]. 0 I III [Hedysarum alpinum], H. alpinum var. americanum (H. americanum), H. mackenzii. Uredinia are absent but secondary aecia may accompany telia on the upper leaf surface. In contrast primary aecia occur in large groups, are hypophyllous and are accompanied by pycnia.

215. U. hedysari-paniculati (Schw.) Farl. 1879. I DEARN, I PUR, 2 TRTC. Range 5, 11, 33. 0 I II III *Desmodium canadense, D. glabellum (D. dillenii). Pycnia and aecia are not present in the Ontario specimens.

216. U. holwayi Lagerh. 1889. 2 DAOM, 2 DEARN, 2 PUR, 8 TRTC. Range 4, $5,8,11,19$. O I II III Lilium canadense, L. michiganense, *L. superbum, Lilium $\mathrm{sp}$.

217. U. junci (Desm.) Tul. 1854. O I Aster macrophyllus PUR 13126 (TRTC J.H. Faull 4910) Nipissing Dist. II III Juncus spp. not known in Ontario.

218. *U. junci-effusi Syd. 1910. O I not known. II III on Juncus effusus DAOM 59425 Middlesex Co. The single specimen from Ontario bears only telia (cf. $U$. silphii).

219. U. lespedezae-procumbentis (Schw.) Curt. 1867. 6 DAOM, 4 DEARN, 2 PUR, 11 TRTC. Range 2, 4, 5, 8, 10, 11, 19, 40. 0 I II IIl Lespedeza capita *L. hirta, $*$ L. intermedia (L. frutescens), Lespedeza sp. To date only uredinia and telia have been collected in Ontario. 
220. U. limonii (DC.) Lev. 1849. 0 I II III Limonium vulgare DEARN 3161 Essex Co., DAOM 20816 Wellington Co. Arthur (1934) included with this species, but under varietal rank, the rust on Armeria. The latter was given specific status by Savile and Conners in 1951 at which time they described U. limonii-caroliniani for an opsis-form on Limonium carolinianum (L. nashii) long confused with $U$. limonii. U. limonii-caroliniani is known from Quebec but its host is absent from Ontario.

221. U. lineolatus (Desm.) Schroet. 1876 (U. scirpi (Cast.) Burr. 1884). I DAOM, 1 PUR, 2 TRTC. Range 25, 40. 0 I Sium suave (S. cicutaefolium) II II Scirpus fluviatilis. Pycnia and aecia are known also on Cicuta spp. (cf. U. americanus).

222. *U. minimus J.J. Davis 1894. O I unknown. II III Muhlenbergia glomerata (M. racemosa) DAOM 51843 Bruce Co.

223. U. nerviphilus (Grog.) Hotson 1925. 0 I III Trifolium repens DEARN 1302, 3372 Middlesex Co., TRTC 2172, 30389 York Co. This is essentially an opsisform of U. trifolii.

224. U. perigynius Halst. 1889. I DEARN, 3 PUR, I TRTC. Range 5, 8. 0 I No Ontario collections, but reported to occur on Compositae (Rudbeckia lacinata and Solidago rugosa). II III *Carex bebbii, C. cristatella, C. tribuloides.

225. U. phaseoli (Reben.) Wint. 1881. 4 DAOM, 4 DEARN, 1 PUR, 5 TRTC. Range $1,2,4,5,10,15,17,19,40.0$ I II III.*Amphicarpa bracteata; *Phaseolus coccineus, P. vulgaris; Strophostyles helvola. In some years bean rust may be of local importance. For instance rust was sporadic in southwestern Ontario prior to 1947 but in that year it became widespread and caused severe damage (Canadian Plant Disease Survey for 1947). Arthur (1934) recognizes three varieties.

226. U. polygoni-avicularis (Pers.) Karst. 1879 (U. polygoni (Pers.) Fckl. 1870). 4 DAOM 4 DEARN, 5 PUR, 5 TRTC. Range 2, 5, 8, 11, 19, 40, 45, 47 and [Montreal area, Que.]. 0 I II III Polygonum aviculare, *P. erectum, P. hydropiperoides, $* P$. ramossissimum, Polygonum $\mathrm{sp}$.

227. U. rhyncosporae Ellis 1893. O I unknown. II III Rhynocospora alba DEARN 3106 (PUR 12480-12484 incl., TRTC 6831) Middlesex Co., DAOM 46171 Waterloo Co., DAOM 28061 Parry Sound Dist. The Dearness material is in excellent condition and shows extremely heavy infection. The site was revisited in 1958 in an attempt to find the alternate host. Although Rhyncospora was moderately abundant, rust was not evident on either the past or current season plants.

228. U. rudbeckiae Arth. \& Holw. in Arth. 1884. III Rudbeckia laciniata DEARN 1976 (PUR 38754), PUR 38732 Middlesex Co.

229. U. silphii Arth. 1907. 4 DAOM, I DEARN, I PUR, 7 TRTC. Range 5, 19, 40,45, 47 and [Gatineau area, Que.]. 0 I Aster macrophyllus. II III *Juncus 
dudleyi, *J. effusus, J. tenuis (J. macer), Juncus sp.; Helianthus and Silphium are also known to support pycnia and aecia. Three species of Uromyces are reported on Juncus in North America, $U$. junci and $U$. junci-effusi are also reported from Ontario.

230. U. sparganii Cke. \& Pk. 1874 (U. pyriformis Cke.).34 DAOM, 2 DEARN, 5 PUR, 3 TRTC. Range 3, 17, 31, 40 and [Buckingham, Hull and Bristol, Que.]. O I Hypericum virginicum. II III Acorus calamus, Sparganium eurycarpum. Parmelee and Savile (1954) have combined U. sparganii and U. pyriformis having shown that they are cross-inocuable, morphologically indistinguishable and have their aecial stage on Hypericum virginicum.

231. U. striatus Schroet. 1870. 23 DAOM, I DEARN, I PUR, 6 TRTC. Range $5,8,11,13,20,25,26,27,28,29,30,40,41,45$. 0 I Euphorbia cyparissias, systemic. II III [Medicago falcata], M. lupulina, M. sativa. The first North American specimens of the 0 I stages were collected at Braeside, Renfrew Co., where Euphorbia was abundant along roadsides and in fields $\mathrm{n}$ ot under cultivation. Rusted Euphorbia has also been found at Hornings Mills, Dufferin Co.; there the host flourishes in areas fallen into disuse and, as at Braeside, the soil is decidedly light, even gravelly. At both sites Medicago, Trifolium, Vicia and Melilotus were all associated with infected Euphorbias but uredinia and telia developed only on the Medicago.

232. U. trifolii (Hedw. f. ex D.C.) Lev. 1847. 13 DAOM, 3 DEARN, 3 PUR, 21 TRTC. Range 1, 5, 9, 11, 17, 19, 20, 21, 25, 26, 27, 40, 45, 47, 49, and [Montreal area, Que.]. 0 I II III Trifolium hybridum, T. pratense, T. repens. The clovers listed were the primary hosts in Arthur's (1934) three varieties, respectively hybridi, trifolii-repentis, and fallens.

233. U. triquetrus Cke. 1862 (U. hyperici (Spreng.) Curt. 1867). 9 DAOM, 4 DEARN, 7 PUR, 12 TRTC. Range 3, 8, 10, 13, 25, 32, 40, 42, 43, 47 and [Gatineau area, Que.]. 0 I II III *Hypericum boreale, ${ }^{*} H$. ellipticum, $H$. kalmianum, ${ }^{*} H$. mutilum, ${ }^{*} H$. punctatum, $H$. spathulatum (H. prolificum), H. virginicum, Hypericum sp. 


\section{References}

Arthur, J.C. (1934) Manual of the rusts of United States and Canada. Purdue Research Foundation, Lafayette, Ind.

Bailey, L.H. (1949) Nanual of cultivated plants. Macmillan Co., New York.

Bisby, G.R. et al. (1938) The fungi of Manitoba and Saskatchewan. National Research Council, Ottawa.

Boyce, J.S. (1957) The fungus causing western gall rust and woodgate rust of pines. Forest Science 3: 225-234.

Cummins, G.B. (1931) Phragmidium species of North America: differential teliospore and aecial characters. Mycologia 23: 433-445.

Cummins, G.B. and Stevenson, J.A. (1956) A check list of North American rust fungi (Uredinales). Plant Disease Survey, U.S.D.A., Beltsville, Md.

Dutilly, A. et al. (1954) Contribution a la flore du versant occidental de la Baie James, Ontario. Contrib. Arctic Inst., S.F. Catholic University of America, Washington, D.C.

Faull, J.H. (1932) Taxonomy and geographical distribution of the genus Milesia. Contribs. Arnold Arboretum Harvard Univ. II. Jamaica Plain, Mass.

Faull, J.H. (1938) Taxonomy and geographical distribution of the genus Uredinopsis. Contribs. Arnold Arboretum Harvard Univ. XI. Jamaica Plain, Mass.

Fernald, M.L. (1950) Gray's manual of botany, 8th ed. American Book Co., New York.

Fox, W.S. and Soper, J.H. (1953) Distribution of some trees and shrubs of the north carolinian zone of southern Ontario. Trans. Royal Can. Inst. 30: 3-7.

Haddow, W.R. and Hill, A.W. (1954) Blister rust reconnaissance in Ontario. Interim Report, Forest Biology Division, Canada Dept. Agriculture, Ottawa.

Hedgecock, G.G. and Siggers, P.V. (1949) Comparison of the pine-oak rusts. U.S.D.A. Tech. Bull. 978, Washington, D.C.

Hiratsuka, N. (1936) A monograph of the Pucciniastreae. Mem. Tottori Agr. Coll. 4, Tottori, Japan.

Hiratsuka, N. (1958) Revision of the taxonomy of the Pucciniastreae. Tokyo, Japan. 
Hylander, N., Jorstad, I., and Nannfeldt, J.A. (1953) Enumeratio Uredinearum Scandinavicarum. Opera Botan. $1: 1$.

Jackson, H.S. (1931) Present evolutionary tendencies and the origin of life cycles in the Uredinales. Mem. Torrey Bot. Club. 18: 1.

Parmelee, J.A. and Savile, D.B.O. (1954) Life history and relationship of the rusts of Sparganium and Acorus. Mycologia 46: 823-836.

Prince, A.E. and Steinmetz (1940) Gymnosporangium rusts in Maine and their host relationships. Maine Bulletin 42: 2 .

Prince, A.E. (1946) Gymnosporanium nidus-avis Thaxter. Farlowia 2: 475-525.

Rehder, A. (1951) Manual of cultivated trees and shrubs (2nd. ed.). Macmillan Co., New York.

Saccardo, P.A. (1912) Sylloge Fungorum 21: 729. Pavia, Italy.

Savile, D.B.O. (1950) North American species of Chrysomyxa. Can. Jour. Res. C 28: 318-330.

Savile, D.B.O. (1951) The relationship of Puccinia praegracilis and Puccinia connersii. Mycologia 43: 456-458.

Savile, D.B.O. (1954) Taxonomy, phylogeny, host relationship and phytogeography of the microcyclic rusts of Saxifragaceae. Can. Jour. Bot. 32: $400-425$.

Savile, D.B.O. (1955) Chrysomyxa in North America-additions and corrections. Can. Jour. Bot. 33: 487-496.

Savile, D.B.O. and Parmelee, J.A. (1956) Some fungal parasites of the Portulacaceae. Mycologia 48: 573-590.

Soper, J.H. Heimburger, L.M. and Garay, L.A. (1957) Shrubs of Ontario, Pt. 1. Ont. Dept. Planning and Development, Toronto.

Sydow, P. and H. (1915) Monographia Uredinearum III: 145. Leipzig. 


\section{INDEX TO HOSTS \\ Numerals refer to species numbers}

\begin{tabular}{|c|c|c|c|}
\hline Abies & $\begin{array}{l}37,39,42,50,52 \\
53,54,186,187 \\
195,196,197,198 \\
199,200,201\end{array}$ & $\begin{array}{l}\text { Armeria } \\
\text { Artemesia } \\
\text { Asclepias }\end{array}$ & $\begin{array}{l}206 \\
130 \\
169,207\end{array}$ \\
\hline Achillea & 138 & Asparagus & 77 \\
\hline $\begin{array}{l}\text { Acorus } \\
\text { Áctaea }\end{array}$ & $\begin{array}{l}230 \\
165\end{array}$ & Aster & $\begin{array}{l}13,78,103,217 \text {, } \\
229\end{array}$ \\
\hline Agrimonia & 183 & A.thyrium & 198 \\
\hline Agropyron & $99,113,165$ & Avena & 99,113 \\
\hline Agrostis & $99,113,125,153$ & Bellis & 141 \\
\hline Alopecurus & 113,165 & Berberis & 113,162 \\
\hline Althea & 132 & Betula & 51 \\
\hline Ambrosia & 87,182 & Bidens & 142 \\
\hline Amelanchier & $29,30,31,35$ & Briza & 113 \\
\hline Ammophila & 113 & Bromus & 165 \\
\hline Amphicarpa & 225 & Calamagrostis & 99 \\
\hline Andropogon & 69,107 & Calamovilfa & 173 \\
\hline Anemone & $\begin{array}{l}70,131,158,165 \\
193,194\end{array}$ & $\begin{array}{l}\text { Calistephus } \\
\text { Caltha }\end{array}$ & $\begin{array}{l}13 \\
85,86\end{array}$ \\
\hline Angelica & 71 & Campanula & 11 \\
\hline Antirrhinum & 73 & Cardamine & 74 \\
\hline Arctium & 80 & Carthamus & 90 \\
\hline Arctostaphylos & 3,191 & $\begin{array}{l}\text { Centaurea } \\
\text { Cephalanthus }\end{array}$ & $\begin{array}{l}90,101 \\
169\end{array}$ \\
\hline Arenaria & 76 & Cerastium & 50,76 \\
\hline
\end{tabular}




\begin{tabular}{|c|c|c|c|}
\hline Chaerophyllum & 151 & Dirca & 1,103 \\
\hline Chamaedaphne & 6 & Draba & 104,175 \\
\hline Chrysanthemum & 91 & Dryopteris & $37,52,53,196,200$ \\
\hline Cichorium & 118 & Dulichiurn & 103 \\
\hline Cicuta & 92,221 & Elaeagnus & 89 \\
\hline Cimicifuga & 165 & Eleocharis & 106 \\
\hline Cinna & 113 & Elymus & $99,113,165$ \\
\hline Circea & 93 & Empetrum & 5 \\
\hline Cirsium & $84,95,161$ & Epilobium & $103,109,186$ \\
\hline Clarkia & 185 & Erigenia & 110 \\
\hline Claytonia & 23,123 & Erigeron & 103 \\
\hline Clematis & 165 & Eriophorum & 72 \\
\hline Clintonia & 136 & Erythronium & 168 \\
\hline Comandra & 17,69 & Eupatorium & 106,174 \\
\hline Comptonia & 18 & Euphorbia & $44,146,209,210,231$ \\
\hline Convolvulus & 98 & Festuca & 99,113 \\
\hline Cornus & 156 & Fraxinus & 172 \\
\hline Crataegus & $29,30,33$ & Galium & $159,160,167,188$ \\
\hline Cryptogramma & 38 & Gaultheria & 4 \\
\hline Cryptotaenia & 100 & Gentiana & 112,114 \\
\hline Cydonia & 30 & Geocaulon & 17,96 \\
\hline Cyperus & 87 & Geranium & 155,212 \\
\hline Cystopteris & 38,197 & Glyceria & 113 \\
\hline Dactylis & 113 & Gnaphalium & 120 \\
\hline Decodon & 139 & Habenaria & 157 \\
\hline Deschampsia & 157 & Halenia & 114 \\
\hline Desmodium & 215 & Hedysarum & 214 \\
\hline Dianthus & 209 & Helianthus & 115,229 \\
\hline
\end{tabular}




\begin{tabular}{|c|c|c|c|}
\hline Hepatica & 194 & Lycopsis & 165 \\
\hline Heuchera & 117 & Lycopus & 72,165 \\
\hline Hieracium & 111,118 & Lysimachia & $102,127,203$ \\
\hline Hordeum & 113,119 & Mahonia & 22 \\
\hline Hydrophyllum & 120 & Malva & 132 \\
\hline Hypericum & 230,231 & Matteuccia & 201 \\
\hline Impatiens & 165 & Medicago & 231 \\
\hline Iris & 122,168 & Melampyrum & 16 \\
\hline Juncus & $217,218,229$ & Melilotus & 231 \\
\hline Juniperus & $\begin{array}{l}28,29,30,31,32, \\
33,34,35\end{array}$ & $\begin{array}{l}\text { Mentha } \\
\text { Milium }\end{array}$ & $\begin{array}{l}72,135 \\
113\end{array}$ \\
\hline Koeleria & 125,140 & Mitella & 116 \\
\hline Lactuca & 103 & Monarda & 135 \\
\hline Lapsana & 124 & Moneses & 8 \\
\hline $\begin{array}{l}\text { Larix } \\
\text { Lathyrus }\end{array}$ & $\begin{array}{l}45,47,48,51 \\
211\end{array}$ & Muhlenbergia & 222 \\
\hline $\begin{array}{l}\text { Lathyrus } \\
\text { Ledum }\end{array}$ & $6,7,10$ & Myosotis & 105 \\
\hline $\begin{array}{l}\text { Ledum } \\
\text { Leersia }\end{array}$ & $\begin{array}{l}6,7,10 \\
213\end{array}$ & Myrica & 18 \\
\hline $\begin{array}{l}\text { Leersia } \\
\text { Lespedeza }\end{array}$ & $\begin{array}{l}213 \\
219\end{array}$ & (Nabalus) & $79,103,143$ \\
\hline $\begin{array}{l}\text { Lespedeza } \\
\text { Liatris }\end{array}$ & $\begin{array}{l}219 \\
125\end{array}$ & Oenothera & 103 \\
\hline $\begin{array}{l}\text { Liatris } \\
\text { Ligusticum }\end{array}$ & 126 & Oncidium & 202 \\
\hline $\begin{array}{l}\text { Ligusticum } \\
\text { Lilium }\end{array}$ & & Onoclea & 195 \\
\hline $\begin{array}{l}\text { Lilium } \\
\text { Limonium }\end{array}$ & & Ornithogalum & 202 \\
\hline $\begin{array}{l}\text { Limonium } \\
\text { Linum }\end{array}$ & 220 & Oryzopsis & 162 \\
\hline $\begin{array}{l}\text { Linum } \\
\text { Lobelia }\end{array}$ & $\begin{array}{r}46 \\
129\end{array}$ & Osmorhiza & 152 \\
\hline $\begin{array}{l}\text { Lobelia } \\
\text { Lolium }\end{array}$ & $\begin{array}{r}129 \\
99\end{array}$ & Osmunda & 199 \\
\hline $\begin{array}{l}\text { Lolium } \\
\text { Luzula }\end{array}$ & $\begin{array}{r}99 \\
141\end{array}$ & Oxalis & 145,171 \\
\hline $\begin{array}{l}\text { Luzula } \\
\text { Lycium }\end{array}$ & $\begin{array}{l}141 \\
176\end{array}$ & Panax & 75 \\
\hline Lycium & & Panicum & 108,146 \\
\hline
\end{tabular}




\begin{tabular}{|c|c|c|c|}
\hline Pedicularis & 94 & Pyrus & $30,32,34$ \\
\hline Peltandra & 205 & Quercus & 19 \\
\hline Penstemon & 69 & Ranunculus & $82,105,158,165$ \\
\hline Petasites & 97 & Rhamnus & 99 \\
\hline Phalaris & 168 & Rheum & 148 \\
\hline Phaseolus & 225 & Rhus & $26,27,67$ \\
\hline Phleum & 114 & Rhyncospora & 227 \\
\hline Phlox & 152 & Ribes & $20,49,88,166$ \\
\hline Phragmites & 131,148 & Rosa & $56,59,61,63,66$ \\
\hline Physalis & 1,149 & Rubus & $\begin{array}{l}40,58,64,65,184 \text { ، } \\
185\end{array}$ \\
\hline $\begin{array}{l}\text { Physostegia } \\
\text { Picea }\end{array}$ & $4,5,6,7,8,9,10$ & Rudbeckia & 224,228 \\
\hline & $50,184,185,191$ & Rumex & $68,144,148$ \\
\hline Pinus & $\begin{array}{l}11,12,13,14,16,17 \\
18,19,20,21\end{array}$ & Salix & $42,43,48,49$ \\
\hline Pisum & 211 & sambucus & 83 \\
\hline Poa & 113,153 & Sanicula & 134 \\
\hline Podophyllum & 154 & Satureja & 135 \\
\hline Polygala & 163 & Saxifraga & $43,117,147$ \\
\hline Polygonum & & Scirpus & $72,142,204,221$ \\
\hline Polvnodium & $01,140,130,220$ & Secale & 113,165 \\
\hline Polypodium & 54 & Senecio & 72,164 \\
\hline Populus & $41,45,47$ & Sempervivum & 24 \\
\hline Potentilla & $25,57,60,62,189$ & Shepherdia & 89 \\
\hline Prenanthes & $79,103,143$ & Silphium & 170,229 \\
\hline Prunus & 194 & Sium & 221 \\
\hline Ptelea & 181 & Smilacina & 168,173 \\
\hline (Pteretis) & 201 & Solidago & $12,13,177,224$ \\
\hline Pycnanthemum & 136 & Sparganium & 230 \\
\hline Pyrola & 8,190 & & \\
\hline
\end{tabular}




$\begin{array}{lclc}\text { Spartina } & 169,172,203 & \text { Trisetum } & 140,153 \\ \text { Spergula } & 76 & \text { Triticum } & 113,165 \\ \text { Sphenopholis } & 105 & \text { Tsuga } & 41,183,192 \\ \text { (Steironema) } & 102,203 & \text { Urtica } & 88,122 \\ \text { Stellaria } & 50,76 & \text { Vaccinium } & 187,192 \\ \text { Stipa } & 140 & \text { Valeriana } & 122 \\ \text { Strophostyles } & 224 & \text { Vernonia } & 14 \\ \text { Taenidia } & 71 & \text { Viburnum } & 15,128 \\ \text { Taraxacum } & 118 & \text { Vicia } & 208,211,231 \\ \text { Thalictrum } & 165,193 & \text { Vinca } & 178 \\ \text { Tiarella } & 116 & \text { Viola } & 107,179 \\ \text { Tovara } & 155 & \text { Waldsteinia } & 180 \\ \text { Trientalis } & 123 & \text { Xanthium } & 87,182 \\ \text { Trifolium } & 223,231,232 . & \text { Zea } & 171 \\ \text { Trillium } & 213 & \text { Zizia } & 71 \\ \text { Triodia } & 181 & \text { Zygadenus } & 79\end{array}$




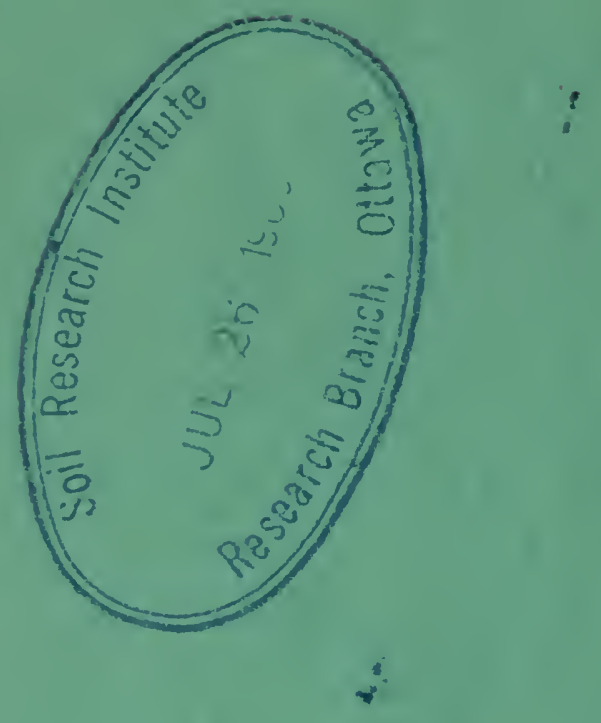

Copies of this publication may be obtained from: Information Division

Canada Department of Agriculture Ottawa, Ontario 